\title{
The Kačák event (late Eifelian, Middle Devonian) on the Belgian shelf and its effects on rugose coral palaeobiodiversity
}

\author{
Valentin Jamart \& Julien Denayer
}

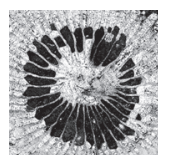

\begin{abstract}
The Devonian is a period that recorded many biocrises. One of them, known as the Kačák event ranges through the Polygnathus ensensis Zone immediately before the Eifelian-Givetian boundary (Middle Devonian). This crisis has been identified in many localities worldwide, mostly in bathyal settings. The event, divided into two phases (otomari event and Kačák event s.s.), is typically marked by a turnover among pelagic faunas, especially conodonts, dacryoconarids and ammonoids. This turnover result from a transgression associated with anoxia that generally corresponds to the deposition of black shale in deep-water settings. In Belgium, the Kačák event s.s. corresponds to a time window equivalent to the deposition of the Lomme and Hanonet formations. New stratigraphic and palaeontological (rugose corals) data show that the Kačák event had a moderate to weak impact on the Belgian carbonate shelf ecosystem. The Old World Realm faunal assemblages show no significant variation in diversity across the Kačák event. Nevertheless, the remarkable and unexpected occurrence of some rugose corals typical of the East American Realm (siphonphrentids and heliophyllids) in the lower part of the Hanonet Formation helps identify the event as the latter is also marked by a short phase of cosmopolitanism of benthic fauna. This is a proposed criterion useful to recognize the Kačák event where the typical pelagic guides are missing. - Key words: biocrisis, extinctions, palaeobiogeography, stratigraphy, cosmopolitanism, invasive taxa.
\end{abstract}

Jamart, V. \& Denayer, J. 2020. The Kačák event (late Eifelian, Middle Devonian) on the Belgian shelf and its effects on rugose coral palaeobiodiversity. Bulletin of Geosciences 95(3), 279-311 (12 figures, appendix). Czech Geological Survey, Prague. ISSN 1214-1119. Manuscript received February 8, 2020; accepted in revised form June 1, 2020; published online August 9, 2020; issued August 9, 2020.

Valentin Jamart \& Julien Denayer, Evolution \& Diversity Dynamics Lab, U.R. Geology, Université de Liège, 14 Allée du Six-Août, B18, Sart Tilman,4000Liège,Belgium; vjamart@uliege.be, julien.denayer@uliege.be

During the Devonian period, major continents/blocks were located in the southern hemisphere (e.g. Stampfli et al. 2002, 2013; Scotese 2014), with a major mountain range running on the northeastern margin of Laurussia to Gondwana: the Appalachian range (Fig. 1) (DeSantis 2010, Scotese 2014). This period of time is marked by one of the most significant modifications in palaeobiogeography with the precipitated end of the strong faunal endemism of the Emsian-Eifelian and the initiation of the GivetianFrasnian cosmopolitanism (Oliver \& Pedder 1979b).

During the early Emsian to late Eifelian interval, three distinct faunal assemblages allow the definition of three different marine realms (Oliver \& Pedder 1979a, 1979b, 1994; May 1995, 1997b), separated by various barriers. The Malvinokaffric Realm (MKR), located along the margins of Gondwana (Fig. 1), is relatively poor in corals and it is characterized by cold-water species (Oliver 1990; Oliver \& Pedder 1979a, 1979b, 1994; May 1995, 1997b). The East Americas Realm (EAR), located on the eastern part of North America and the northern part of South
America (Fig. 1), is characterized by subtropical marine faunas and high degree of endemism (Oliver 1990; Oliver \& Pedder 1979a, 1979b, 1994; May 1995, 1997b). The Old World Realm (OWR) covers the Palaeothetys Ocean and the margins of Laurussia, Kazakhstania and Siberia as well as the Chinese blocks and E Australian terranes (Fig. 1). It is also characterized by widespread subtropical marine faunas (Oliver 1990; Oliver \& Pedder 1979a, 1979b, 1994; May, 1995, 1997b). The EAR is isolated from the OWR by a continental arch (Fig. 1) and the Appalachian mountain range (Oliver \& Pedder 1979a; May 1995, 1997b).

Whereas the lowest sea level of the Devonian was recorded during the Emsian (May 1995, 1997b), the Middle Devonian recorded one transgressive pulse. This eustatic increase led to the collapse of the continental arch that separated the EAR from the OWR, and to the opening of a passageway allowing the migration of marine faunas between the two realms (Oliver \& Pedder 1979a, DeSantis \& Brett 2011). The faunal turnovers observed in the EAR are a probable consequence of this major 
palaeobiogeographic change and most probably amplified the effects of the Kačák biocrisis (May 1995). Consequently, the end of the Eifelian stage was marked by both eustatic and palaeobiogeographic major changes (May 1995, Boucot et al. 1997, DeSantis \& Brett 2011).

\section{The Kačák event}

During the Devonian, many biocrises have been identified (May 1995; House 1985, 1996). These crises are generally defined in bathyal settings, based on changes among pelagic faunas such as ammonoids and conodonts (Walliser 1996) but few or no extinction affecting the benthic faunas.

During the late Eifelian, the Kačák event (House 1985 ) is marked by faunal turnovers and by rapid facies changes, probably induced by a change of oxygenation in the water column in response to eustatic and/or temperatures variations (Chlupáč \& Kukal 1986, DeSantis \& Brett 2011). The Kačák event extended through the entire ensensis Zone directly below the Eifelian-Givetian boundary (House 1996, Walliser 1996, Schöne 1997).

This event was initially identified by the presence of anoxic black shale of the Kačák Member (Mb.) of the Srbsko Formation (Fm.) in the Barrandian area of Czech Republic (Chlupáč \& Kukal 1986, 1988; Budil 1995; May 1995; House 1985, 1996). The black shale has a depleted fauna but ammonoids recovered from the units above the anoxic horizon differ significantly from those yielded by the level below the black shale (House 1985). Chlupáč \& Kukal (1988) identified this horizon as an extinction event followed by a rapid radiation. Based on pelagic faunal changes, the event was subsequently identified in many localities worldwide, e.g. Rhenish Mountains in Germany (May 1995, House 1996, Schöne 1997, Königshof et al. 2016), Cantabrian zone and Asturian coast in Spain (Truyóls-Massoni et al. 1990, House 1996, GarcíaAlcalde \& Soto 1999, García-López et al. 2002), Scotland and SW England (House 1996, Marshall et al. 2007), Montagne Noire in France (House 1996), Carnic Alps in Austria (DeSantis \& Brett 2011), Antiatlas in Morocco (House 1996, Becker et al. 2013), U.S.A. (DeSantis 2010, DeSantis \& Brett 2011), Ontario province in Canada (van Hengstum \& Gröcke 2008), Falkland Islands (Marshall 2016), Bolivia (Troth et al. 2011), Brasil (Horodyski et al. 2014), South China (House 1996, Qie et al. 2018), Australia (Talent et al. 1993, House 1996), and Vietnam (Königshof et al. 2017).

The Kačák event can be separated into two distinct phases spread over about 200 kyr (Walliser 1996, Schöne 1997, DeSantis 2010, Ellwood et al. 2011, Kido \& Suttner 2011). The first phase - otomari event or rouvillei event or Ei 1 (in Walliser 1996) - corresponds to the base of the ensensis conodont Zone and is characterized by the onset of anoxic black shales in many localities. It is also coincident with the boundary between the kockelianus and ensensis conodont zones and is associated to the spread of the dacryoconarid Nowakia otomari and the goniatite Cabrieroceras crispiforme $(=C$. rouvillei $=$ C. plebeiforme) (House 1985; Chlupáč \& Kukal 1986, 1988; Walliser 1996; Schöne 1997; DeSantis 2010; Ellwood et al. 2011). The black shale was deposited during a rapid rise of the sea level that triggered the abrupt development of anoxic conditions in the basin (Chlupáč $\&$ Kukal 1988). The second phase - Kačák event s.s. or Ei 2 (in Walliser 1996) - immediately before the EifelianGivetian boundary, is characterized by the end of the black shale deposition combined with numerous extinctions among goniatites (House 1996, Walliser 1996, Schöne 1997, DeSantis 2010, Ellwood et al. 2011). Marshall et al. (2007) suggested that a change in insolation could have triggered the event through an increase of temperature and consecutive stratification of oceanic water and development of anoxia transported towards the shelves by the correlative transgression (May 1995). The increase in precipitation (recorded as immature silicoclastic deposits correlated with the Struve's "Great Gap", Struve 1982) would also have strongly decreased the salinity of seawater, eliminating the stenohaline organisms from the continental margins (May 1995, Marshall et al. 2007).

However, in basin settings, the sedimentary accumulation is slow and discontinuous and the resulting thickness is reduced, in the so-called condensed sections. Crises are there recorded as thin intervals and extinctions appear as abrupt events. It is the case for the Jebel Mech Irdane section (Moroccan Tafilalt) where the Kačák event is characterized by $0.5 \mathrm{~m}$ of anoxic black shales (Becker \& House 1994, House 1996). In the Barrandian sections (Czech Republic) the event is marked by the abrupt onset of $0.5-3 \mathrm{~m}$ of anoxic black shales or equivalent (e.g. 'dark interval' in the Koněprussy area, Hladil \& Kalvoda 1993, Budil 1995) associated with a faunal turnover (Chlupáč \& Kukal 1986, 1988; Budil 1995; May 1995; House 1996). Conversely, in platform and ramp settings, the sedimentary accumulation is much higher, the sections are 'uncondensed' and the crises are often less well-marked due to the signal dilution. Extinction/turnover seems to be more gradual and lithological changes are more progressive. This dilution can nevertheless been regarded as a good opportunity to understand the succession of events within the event.

The development and effects of the Kačák event on shelves is not as well understood as those in bathyal settings. In the Rhenish Mountains, in neritic and hemipelagic facies, the Kačák event was identified in the Bonzel Fm.: the otomari event is recognized in the calcareous siltstones of the Bonzelhammer $\mathrm{Mb}$. (lower part of the Bonzel Fm.) and the Kačák event s.s. corresponds to the 
Figure 1. Evolution of landmasses and biogeographic realms in the Emsian (A), Eifelian (B) and Givetian (C). Legend \& abbreviations: 1 - Carnic Alps; 2 - Prague Basin; 3 - Spain; 4 - Antiatlas; 5 - central North America; 6 - Scotland; 7 Namur-Dinant Basin; 8 - Rhenish Mountains; 9 - Western Urals; 10 - South China blocks; 11 Western Australia; 12 - Bolivia; 13 - Vietnam; 14 - Brazil; 15 Falkland Islands; EAR - East Americas Realm; OWR - Old World Realm; Kz - Kazakhstania; NC - North China. Modified from Kido \& Suttner (2011) and Scotese (2014).
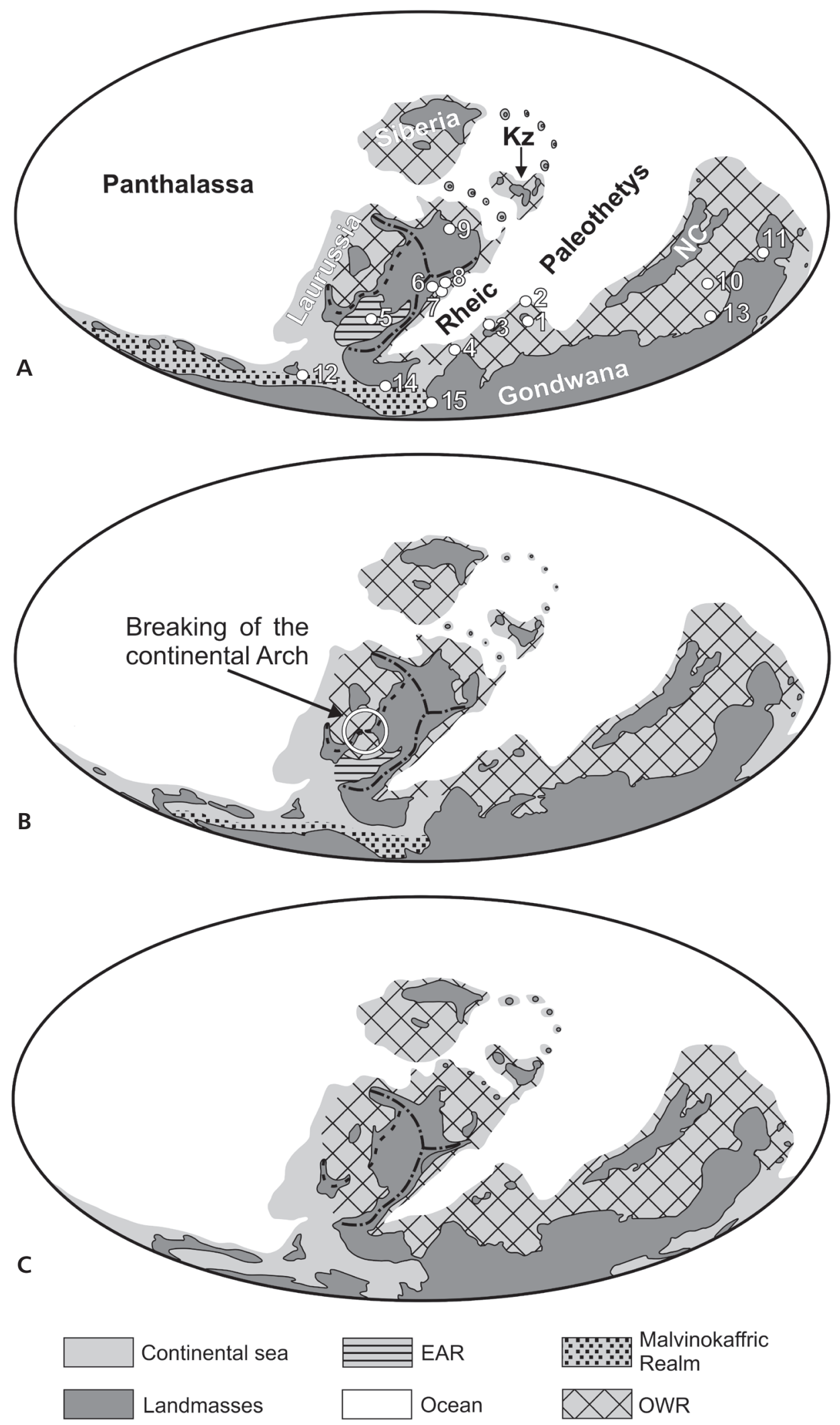

Appalachian
Range 
nodular limestone-bearing siltstone of the Senkel Mb. (upper part of the Bonzel Fm.) (Schöne 1997). In the Eifel, the event is marked by dark shale extending from the upper part of the Junkenberg Fm. (Giesdorf Mb.) to the lower part of the Freilingen Fm. (Eilenberg Mb.) (House 1996; May 1997a, b; DeSantis 2010). The onset of this shale coincides with a major $\delta^{13} \mathrm{C}$ positive excursion (Königshof et al. 2016). This dark shale has a development of $\sim 45 \mathrm{~m}$ (House 1996).

Gouwy \& Bultynck (2003) suggested that in Belgium, the Kačák event corresponds to a $32 \mathrm{~m}$-thick unit comprising the upper part of the Jemelle Fm. and the lower part of the Hanonet Fm. (see Geological and stratigraphic settings). However, biotic evidence for precisely placing the event was not provided convincingly by these authors. Based on ostracod diversity, Casier et al. (1992) indicated that there is no evidence for any anoxic phase associated to the Kačák event in the Hanonet Fm.

\section{Faunal impacts of the event}

As explained earlier, the Kačák event is associated with major changes in paleobiogeography, notably through the dismantlement of the MKR (May 1995, 1997a, 1997b; Walliser 1996; Boucot et al. 1997; Horodyski et al. 2014) and the replacement of mostly endemic EAR faunas by cosmopolitan taxa (Oliver 1990, Oliver \& Pedder 1979a, May 1995). Even if major exchanges were mainly from the OWR towards the EAR, some invasions from the EAR towards the OWR were also identified (Schröder 1997b). Oliver \& Pedder (1979b) suggested that the invading taxa coming from the OWR overwhelmed the EAR endemic taxa because the latter were less diverse and probably more adapted to quiet confined shallow water settings of E North America.

A significant loss of diversity was documented among anacerids (ammonoids) in the upper Eifelian before the

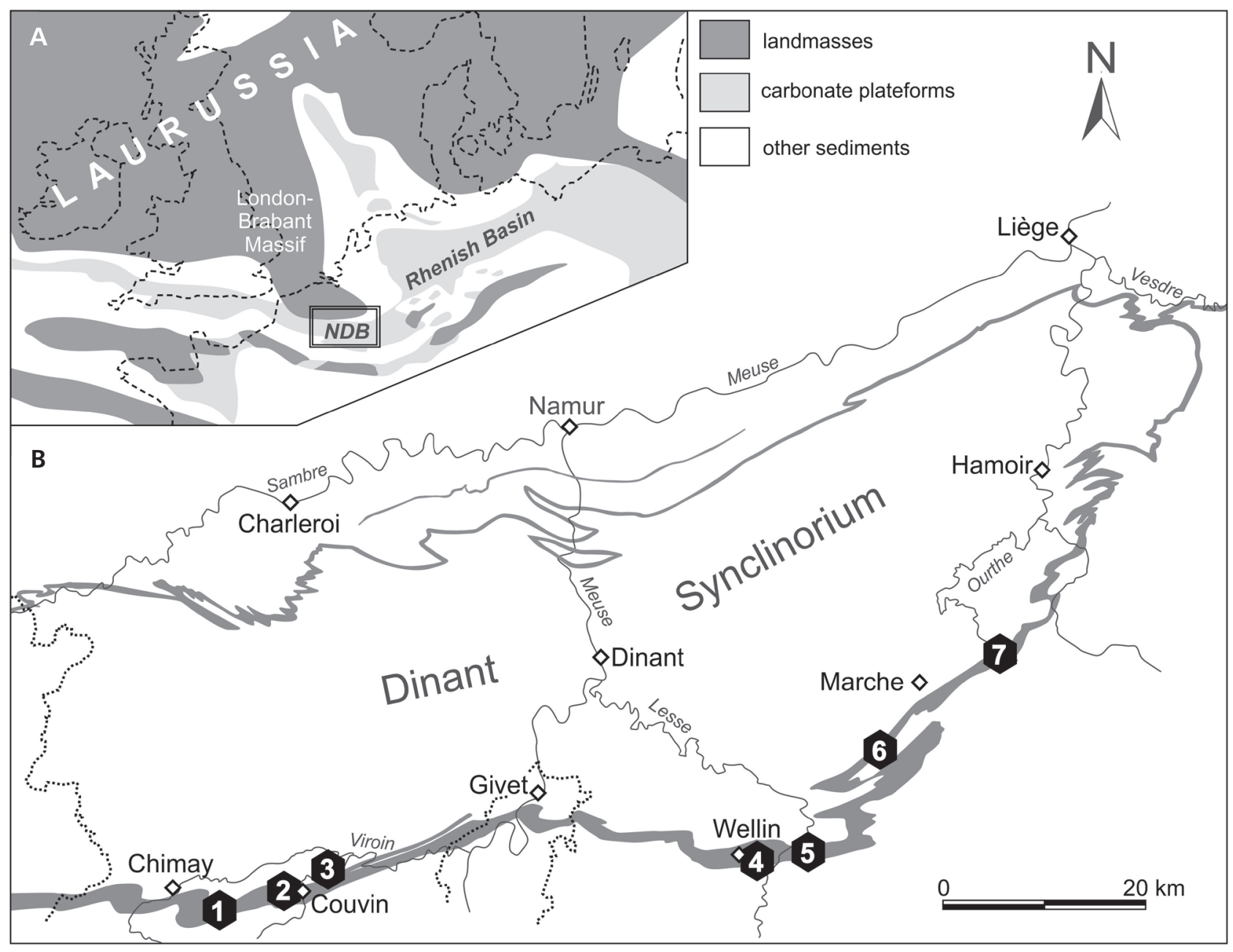

Figure 2. Location and geological settings of the Namur-Dinant Basin. • A - palaeobiogeographic context of southern margin of Laurussia. • B - sampled localities along the southern margin of the Dinant Synclinorium. Legend: 1 - Baileux; 2 - Couvin; 3 - Nismes; 4 - Wellin; 5 - Resteigne; 6 - Jemelle; 7 - Hampteau. The Eifelian strata are represented by the grey line. Modified from Ziegler (1982) and Denayer (2019). 
Figure 3. Stratigraphic chart for the upper Eifelian and the lower Givetian in southern Belgium. In Lithostratigraphy: formations names are in bold whereas the others are members. Legend \& abbreviations: 1 - Baileux; 2 Couvin; 3 - Nismes; 4 - Wellin; 5 - Resteigne; 6 - Jemelle; 7 Hampteau; MD - Middle Devonian sequence; LST - lowstand system tract; TST - transgressive system tract; HST - highstand system tract; TSA - Tienne Sainte-Anne Member. Modified from Denayer (2019).

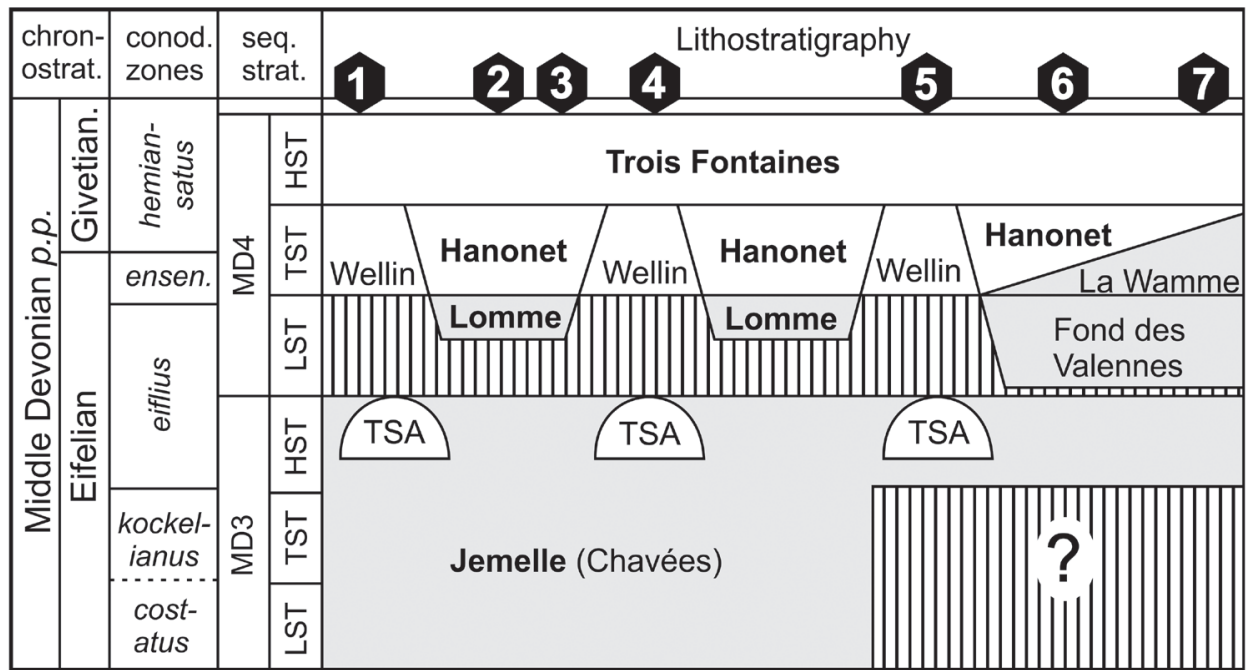

lower Givetian radiation of the tornoceratids (House 1985, DeSantis 2010, DeSantis \& Brett 2011). Immediately before and during the event, a turnover is observed with several genera becoming extinct, whereas other radiates (e.g. Agoniatites, Maenioceras, Cabrieroceras crispiforme, Holzapfeloceras and Wedkindella) (House 1985, 1996; Chlupáč \& Kukal 1986, 1988; Walliser 1996; Chlupáč et al. 2000; DeSantis 2010).

Turnovers were identified among conodonts with extinctions of many species of the genera Polygnathus and Tortodus (including To. kockelianus) and the radiation of Icriodus and polygnathidae such as Po. ensensis (Walliser 1996, Schöne 1997, DeSantis 2010, DeSantis \& Brett 2011).

A similar pattern is observed with the dacryoconarids with the sudden appearance of Nowakia otomari as index taxa of the event and the disappearance of $N$. chlupaciana (Chlupáč \& Kukal 1988, Budil 1995, Schöne 1997, Chlupáč et al. 2000, DeSantis \& Brett 2011).

In the Rhenish Mountains, in Germany, May (1995, 1997a, 1997b) and Schöne (1997) suggested the link between the Kačák event and the appearance of two spiriferidae Mucrospirifer diluvianus and Spinocyrtia (Spinocyrtia) ostiolata known from older strata of EAR.

Beside the significant faunal exchange, the rugose coral diversity has yet been very poorly documented across the event. In Germany the event is marked by a change in the faunal assemblages of corals, from the upper Eifelian Freilingen and Ahbach formations to the lower Givetian; this complete change is not linked to an extinction but to the small decrease of Eifelian corals progressively replaced by Givetian taxa (Oliver \& Pedder 1979a, Oliver 1990, May 1995, DeSantis 2010, Kido \& Suttner 2011).

This paper aims to provide new clues to identify and understand the impact of the Kačák event on the Belgian shelf system, in particular on rugose corals.

\section{Descriptions}

\section{Geological and stratigraphic settings}

During the Middle Devonian, the Namur-Dinant Basin of S Belgium corresponded to a shallow subtropical sea in the southern hemisphere along the southern coast of Laurussia (Fig. 2). From the Emsian to the Eifelian, a mixed carbonate and siliciclastic shelf developed and then evolved into a carbonate platform in the Givetian (Tsien 1969, Préat 1989, Préat \& Kasimi 1995, Mamet \& Préat 2005).

From SW to NE, the Namur-Dinant Basin shows a proximal-distal gradient (Kasimi \& Préat 1996, Gouwy \& Bultynck 2003). The Eifelian is well exposed in the Couvin and Wellin areas $(\sim 750 \mathrm{~m})$ that correspond to the deepest part of the basin where continuous subsidence allowed a complete record (Kasimi \& Préat 1996, Bultynck \& Dejonghe 2001, Gouwy \& Bultynck 2003). In the northern part of the basin, the thickness is significantly lower (up to $200 \mathrm{~m}$ in the Vesdre area) and the conglomerate-sandstonesiltstone succession recorded more proximal siliciclastic conditions (Bultynck 2006).

A short description of the lithostratigraphy is provided here. For further details, refer to Bultynck et al. (1991), Bultynck \& Dejonghe (2001) and Denayer (2019).

The Jemelle Fm. (Fig. 3) is divided into several members (Bultynck et al. 1991), the upper one (Chavées Mb.) is dominated by shale and calcareous shale with limestone beds and nodules, rich in macrofauna (rugose and tabulate corals, brachiopods, bivalves and trilobites). Godefroid (1968) identified the brachiopod Spinocyrtia ostiolata in the lower part of the Chavées Mb. (kockelianus Zone). In Belgium, this species does not appear in the ensensis Zone, probably for facies reasons and therefore cannot be used as a marker of the Kačák event as it is in Germany 
(May 1995). In the upper part of the Chavées Mb., small bioherms (Tienne Sainte-Anne Mb.) locally develop (Bultynck 1970). The Jemelle Fm. reaches a thickness varying from $300 \mathrm{~m}$ (stratotype) to $600 \mathrm{~m}$ in the WellinResteigne area (Bultynck et al. 1991). This formation belongs to the upper Eifelian costatus to ensensis biozones (Bultynck \& Dejonghe 2001).

The Lomme Fm. (Fig. 3) is dominantly a more or less carbonate sandstone unit, arkosic in places where siltstone beds are not rare. This formation belongs to the upper Eifelian, kockelianus to ensensis biozones. It is stratigraphically equivalent to the upper part of the Jemelle Fm. and the lowermost part of the Hanonet Fm. (Bultynck \& Dejonghe 2001). Denayer (2019) interpreted these silicoclastic deposits as the lowstand system tract of the Middle Devonian third-order sequence MD4. These deposits are well-developped in the eastern part of the Namur-Dinant Basin where the subsidence rate was apparently the highest (Godefroid 1968, Kasimi \& Préat 1996). However siliciclastic deposits equivalent to the Lomme Fm. were reported in other places in the basin, notably in the Couvin area (Barchy \& Marion 1999) where it seems to fill palaeodepressions between the highs formed by the underlying Tienne Sainte-Anne Mb. (Denayer 2019).

The Hanonet Fm. (Fig. 3) is typically made of thin beds of nodular, dark, argillaceous or slightly silty and micaceous limestone alternating with calcareous shale beds (Bultynck et al. 1991) passing progressively upwards to argillaceous limestone rich in brachiopods and corals. The thickness of the formation varies from $50 \mathrm{~m}$ in Couvin, to $70 \mathrm{~m}$ in Resteigne (Bultynck \& Dejonghe 2001). In the stratotype of the formation in Couvin, Bultynck \& Hollevoet (1999) identified the base of the Givetian $17 \mathrm{~m}$ above the base of the formation with the first occurrence of the conodont Po. hemiansatus. The Hanonet Fm. belongs to the upper Eifelian ensensis Zone and the lower part of the Givetian hemiansatus Zone. Denayer (2019) interpreted the Hanonet Fm. as the transgressive system tract of the Middle Devonian third-order sequence MD4, the middle argillaceous dark limestone unit being seen as the maximum flooding surface (or zone) of this sequence.

A peculiar facies contemporaneous with the typically argillaceous limestone of the Hanonet Fm. is recognized as the Wellin Mb. (Fig. 3). It is made of lenticular bodies of well-bedded crinoidal limestone, locally argillaceous, commonly rich in corals and stromatoporoids (CoenAubert et al. 1991). This member reaches a thickness of $115-120 \mathrm{~m}$ in the type locality (Bultynck et al. 1991, Bultynck \& Dejonghe 2001). Laterally, the member shows a progressive transition from crinoidal grainstone to typical argillaceous wackestone-packstone of the Hanonet Fm. In Baileux and Nismes (Fig. 2), intermediate facies between Hanonet Fm. and Wellin Mb. are observed. The
Wellin $\mathrm{Mb}$. is usually located immediately above the bioherms of the Tienne Sainte-Anne Mb. This is easily explained because these bioherms probably provided submarine relief which are more likely to be colonized by crinoids and stromatoporoids (Denayer 2019).

The Trois-Fontaines Fm. (Fig. 3) is divided into three parts. The lower one is made of few meters of thicklybedded crinoidal limestone (Bultynck et al. 1991). The middle unit is characterized by biostromal limestone beds locally containing stringocephalid coquina beds (Bultynck et al. 1991). The depositional environment of this biostrome was abundantly described (Préat et al. 1984, Mamet \& Préat 2005, Coen-Aubert 2008). This unit was interpreted by Denayer (2019) as the highstand system tract of the Middle Devonian MD4. The upper part of the formation is made of well-bedded micritic limestone (Bultynck et al. 1991). The later unit overlying a horizon with traces of emersion is interpreted as the lowstand and transgressive system tract of the next third-order sequence. Based on conodonts, this formation is entirely included in the lower Givetian hemiansatus Biozone (Bultynck \& Dejonghe 2001).

\section{Description of the sections}

Five localities (Baileux, Couvin, Nismes, Resteigne and Jemelle) (Fig. 2, Appendix) located on the southern margin of the Dinant Synclinorium and exposing de Jemelle, Lomme, Hanonet and Trois-Fontaines formations were sampled. Data from the Hampteau and Wellin sections (Fig. 2) where the Wellin Mb. is exposed were included here but the lithological succession is very different and correlations with other sections are not easy (see CoenAubert et al. 1991). The typical facies of the Hanonet Fm. are exposed in the Couvin section (La Couvinoise quarry), Resteigne and Jemelle quarries sections. Based on these three sections, a composite lithological log was established. The resulting composite log displays a succession of eight lithological units in the Hanonet Fm.; these units are here described in ascending order.

Unit 1 ( $5 \mathrm{~m}$-thick) overlies the transition from the Jemelle Fm. to basal Hanonet Fm. (Fig. 4). It is characterized by beds up to $20 \mathrm{~cm}$-thick of bioclastic grainstone to packstone with crinoids, brachiopods and bryozoans and a small proportion of quartz grains. This unit is relatively poor in corals dominated by mud-stickers cylindrical forms such as Acanthophyllum, Mesophyllum and Cystiphylloides. The colonial Thamnophyllum is not uncommon but occurs commonly as fragmented colonies. This unit corresponds to the upper part of the Jemelle and Lomme Fm.

Unit 2 (13 m-thick) (Fig. 4) is characterized by alternation of dark argillaceous limestone in $20 \mathrm{~cm}$-thick beds 
and calcareous shaly interbeds up to $10 \mathrm{~cm}$-thick whereas Unit 3 (9 m-thick) (Fig. 4) shows an increase in argillaceous content. These two units correspond to the lower part of the Hanonet Fm., even if the dark colour of these units could suggest a depletion of oxygen, the presence of an abundant benthic fauna (corals, brachiopods, ostracods, trilobites); the absence of anoxia facies-related taxa and the high degree of bioturbation are evidence for the absence of anoxia. The rugose coral assemblage is more diverse than in the previous unit, with several species of Acanthophyllum, Aristophyllum luetti Coen-Aubert, 1997, Calceola sandalina (Linnaeus, 1771), Chostophyllum dollendorfense Schröder, 1997, Cyathopaedium paucitabulatum (Schlüter, 1880), Cystiphylloides spp., Enallophrentis martinae (Coen-Aubert, 1996), Glossophyllum ceratites (Goldfuss, 1826), Heliophyllum halleri Schröder, 1995, Mesophyllum spp., Spinophyllum incompositum Schröder, 1997, Stringophyllum acanthicum (Frech, 1885), Tryplasma rohrense Glinski, 2001 and Thamnophyllum spp.

Unit 4 (Fig. 4) is characterized by a $20 \mathrm{~m}$-thick regular alternation of argillaceous limestone and calcareous shale and corresponds to the middle part of the Hanonet Fm. It differs from the previous unit by its increasing carbonate content. The coral fauna of this unit is a depleted association with Acanthophyllum spp., Aristophyllum luetti Coen-Aubert, 1997, Calceola sandalina (Linnaeus, 1771), Cyathopaedium paucitabulatum (Schlüter, 1880), Cystiphylloides spp., ?Grypophyllum sp., Macgeea bathycalyx (Frech, 1886), Mesophyllum spp., Microplasma sp., Stringophyllum spp., Tryplasma rohrense Glinski, 2001 and Thamnophyllum spp.

Units 5 (15 m-thick) and 6 (18 m-thick) (upper part of the Hanonet Fm., Fig. 4) are similar in their lithological succession, each of them starts with few metres of more or less argillaceous bioclastic wackestone to packstone in which new faunas appear, then ends with argillaceous bioclastic and slightly bioturbated mudstone to wackestone. Locally (e.g. in Couvin, Fig. 4), thin biostromal beds with stromatoporoids and tabulate corals occur. They yielded the same rugose corals as the previous unit but also included Chostophyllum dollendorfense Schröder, 1997, Cyathophyllum dianthus Goldfuss, 1826, Cystiphylloides macrocystis (Schlüter, 1889), Dohmophyllum spp., Grypophyllum spp. and Keriophyllum mailleuxi (Tsien, 1969). In the uppermost part, Coen-Aubert (1990, 1996, 1998, 2011) reported Sociophyllum torosum (Schlüter, 1881), Stringophyllum acanthicum (Frech, 1885) and Thamnophyllum spp.

Unit 7 (15 m-thick, base of the Trois-Fontaines Fm., Fig. 4) is characterized by roughly stratified almost white crinoidal and bioclastic rudstone passing upwards to stromatoporoid and tabulate coral biostromes capped by stringocephalid coquina. Coen-Aubert (1988, 1990, 1992,
1996, 1997, 1998, 2008, 2011) abundantly documented the lower Givetian rugose coral association composed of Acanthophyllum heterophyllum (Milne-Edwards \& Haime, 1851), A. tortum (Tsien, 1969), A. vermiculare (Goldfuss, 1826), Beugnisastraea kunthi (Schlüter, 1880), B. parvistella (Schlüter, 1882), "Coenophyllum" groessensi Coen-Aubert, 2008, Columnaria intermedia Coen-Aubert, 1990, Fasciphyllum conglomeratum (Schlüter, 1881), F. katranicum (Gorianov in Bulvanker et al., 1968), Keriophyllum mailleuxi (Tsien, 1969), Sociophyllum elongatum (Schlüter, 1881), S. torosum (Schlüter, 1881), Stringophyllum acanthicum (Frech, 1885) and Thamnophyllum occlusum (Tsien, 1969).

The depositional environment and sedimentology of the Hanonet and Trois-Fontaines formations have been abundantly discussed (Casier \& Préat 1990; Casier et al. 1992, 2016; Coen-Aubert 1996, 1997, 1998; Kasimi \& Préat 1996; Mabille \& Boulvain 2008). Kasimi \& Préat (1996) summarized the evolution of the depositional environment as a progressive transition from outer ramp (upper part of Lomme and Jemelle Fm. and the base of the Hanonet Fm.) to median ramp (Hanonet Fm.) to outer platform (lower part of the Trois-Fontaines Fm.) and inner platform (upper part of the Trois-Fontaines Fm.). Local variations due to configuration of the basin (several tectonic blocks) demonstrate many exceptions to the depositional model. Moreover, it records a complete third-order sequence (Denayer 2019).

\section{Distribution of the coral fauna}

The Hanonet Formation is known to be homogeneous in lithology (mostly argillaceous limestone) but also to be very variable at the small scale (Kasimi \& Préat 1996), with rapid lateral changes of facies notably in the Wellin $\mathrm{Mb}$. (Denayer 2019). The faunal composition is also very variable from locality to locality as already mentioned by Coen-Aubert (1996, 1997, 1998) and Godefroid (1995). However, the background faunal composition of the formation is rather uniform, dominated by various species among the genera Acanthophyllum, Cystiphylloides, Mesophyllum and Calceola.

In the upper Eifelian and lowermost Givetian part of the Hanonet Fm. (unit 2 to 4), there is no significant variation in rugose corals diversity, with the notable exception of the co-occurrence of uncommon taxa such as Aristophyllum (occurring from unit 2 and disappearing in unit 6), Enallophrentis and Heliophyllum (both restricted to units 2 and 3). Other common corals are Acanthophyllum, Calceola, Chostophyllum, Cyathopaedium (not found above the unit 4), Cystiphylloides, Glossophyllum (only found in the unit 3), ? Grypophyllum (found from unit 4 to unit 6), Macgeea (found from unit 4 to 6), Mesophyllum, 
Spinophyllum (only found in the unit 2), Tryplasma and Thamnophyllum. The dimensions and development of some long-ranging species (both cystimorphic and septate solitary rugose corals) show no significant change throughout this interval, suggesting a relatively stable environment.

In the Wellin Mb. of the Hanonet Fm., the peculiar crinoidal limestone and associated facies yielded a rather different fauna, including numerous colonial genera such as Cyathophyllum, Dendrostella, Fasciphyllum, Lyrelasma, Neomphyma, Sociophyllum, Thamnophyllum and Xystriphyllum (Coen-Aubert 1989, 1990, 1992; CoenAubert et al. 1991).

In the Givetian part of the formation (unit 5 and 6), a slight decrease of diversity is observed, with the disappearance of some corals such as Aristophyllum, Calceola (not found in unit 6), Chostophyllum, Cyathophyllum, Cystiphylloides, Dohmophyllum (appearing in the unit 5 and disappearing in the unit 6), Grypophyllum (found only in unit 5 and 6), Macgeea, Mesophyllum (not found in unit 6), with the appearance of new taxa such as Sociophyllum and Keriophyllum in unit 5. The major shift occurs right after the boundary between the Hanonet and Trois-Fontaines formations (unit 7 and 8), with the local disappearance of the genera Acanthophyllum, Cystiphylloides, Sociophyllum (except that S. birenheidi and S. torosum are known in the lower part of the TroisFontaines Fm.), Stringophyllum and with the total disappearance of other genera such as Thamnophyllum and the uncommon Keriophyllum which do not occur above the lower part of the Trois-Fontaines Fm. This change is coincident with the shift from ramp settings to platform settings that probably led to the displacement of these opportunistic faunas. In addition the base of the TroisFontaines Fm. recorded the appearance of new taxa such as Beugnisastraea, Columnaria and Centristella (CoenAubert 1988, 1990, 1997) and the development of new species among the genera Sociophyllum, Disphyllum and Thamnophyllum (decribed by Coen-Aubert 1988, 2008).

Apart from these two small changes (turnovers rather than extinctions) near the Eifelian-Givetian boundary and at the Hanonet-Trois-Fontaines transition, rugose and tabulate corals seem not to have been severely affected. The main diversity changes are mostly related to changes in facies. In conclusion, neither coral diversity nor their disparity seems to have changed significantly during the interval corresponding to the Kačák event.

Beside corals, the brachiopod fauna of the Hanonet Fm. was documented by Godefroid (1995), the ostracods were documented by Casier \& Préat (1990) and Casier et al. (1992, 2016), the trilobites by Van Viersen (2007) and Crönier \& Van Viersen (2007) and the conodonts by Bultynck (1970) and Bultynck \& Hollevoet (1999).

\section{Systematic palaeontology}

The rugose coral fauna of the upper Eifelian to lower Givetian Hanonet and equivalent formations were, in part, described by Coen-Aubert (1992, 1996, 1997, 1998, 2000), Coen-Aubert \& Lütte (1990), CoenAubert et al. (1991) and Tsien (1969, except for the type material, all Tsien's specimens are lost). Coen-Aubert $(1988,1992,1996,1997,1998,2000)$ documented in details the following species, hence they will not be redescribed here: Sociophyllum torosum (Schlüter, 1881), Neomphyma dalcqae Coen-Aubert, 1992, Keriophyllum mailleuxi (Tsien, 1969), Acanthophyllum vermiculare (Goldfuss, 1826), A. heterophyllum (Milne-Edwards \& Haime, 1851) and Aristophyllum luetti Coen-Aubert, 1997, Thamnophyllum occlusum (Tsien, 1969) and Grypophyllum cf. denckmanni Wedekind, 1922. Additional information on taxonomy and stratigraphy can be found therein. Moreover, Calceola sandalina (Linnaeus, 1771) was described and discussed by Wright et al. (2010). From the Wellin Mb. ('Formation X' in Coen-Aubert et al. 1991) in its type-locality, Coen-Aubert (1989, 1990, 1992) described Xystriphyllum pachythecum (Glinski, 1955), Cyathophyllum multicarinatum Coen-Aubert, 1989, Fasciphyllum conglomeratum (Schlüter, 1881), Neomphyma delicata Coen-Aubert, 1990, Stringophyllum wadilinum Coen-Aubert, 1989, Lyrelasma mutabilis (Tsyganko, 1977), Sociophyllum semiseptatum (Schlüter, 1881) and S. rolfwerneri (Birenheide, 1979). Some of them are figured in the present paper (e.g. the common genus Acanthophyllum in Fig. 5).The presently described material is reposited in the Palaeontological Collection of the University of Liège.

Class Anthozoa Ehrenberg, 1834

Subclass Rugosa Milne-Edwards \& Haime, 1850

Order Stauriida Verrill, 1865

Family Zaphrentidae Milne-Edwards \& Haime, 1850

\section{Genus Heliophyllum Hall in Dana, 1846b}

Type species. - Heliophyllum halli Milne-Edwards \& Haime, 1850.

Diagnosis. - See Oliver \& Sorauf (2002).

\section{Heliophyllum halleri Schröder, 1995}

Figure 6A, B

*1995a Heliophyllum (Heliophyllum) halleri n. sp.; Schröder, p. 40, pl. 1, figs 6, 7, pl. 2, figs 8-10, pl. 3, figs 11, 12, text-figs 4, 5 .

1995b Heliophyllum (Heliophyllum) halleri n. sp. - Schröder, p. 386, pl. 2, figs 10-13. 
Valentin Jamart \& Julien Denayer • The Kačák event on the Belgian shelf and its effects on rugose coral palaeobiodiversity

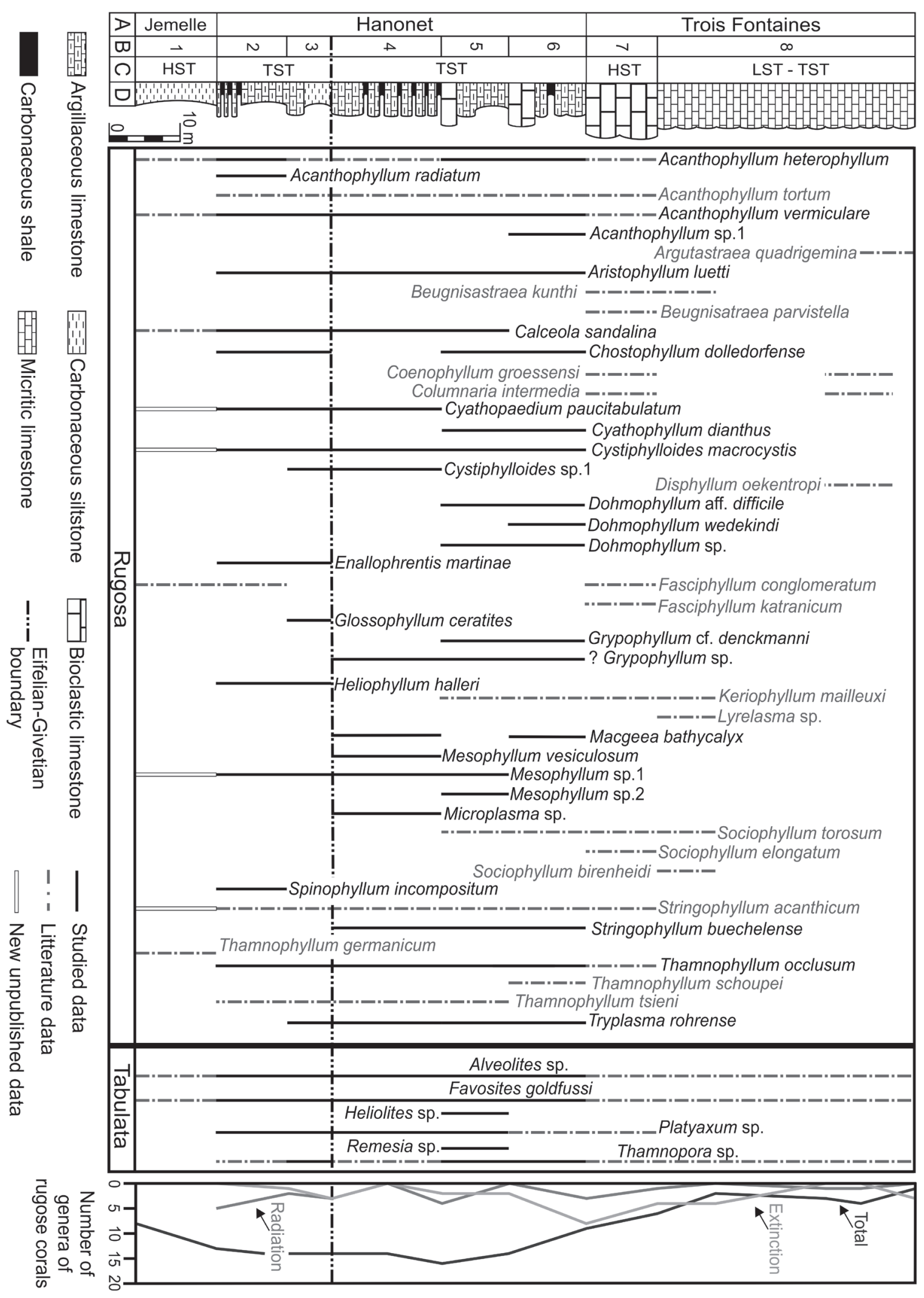

Figure 4. Stratigraphic distribution of rugose and some tabulate corals in the Jemelle, Hanonet and Trois-Fontaines formations. Legend: A - lithostratigraphy; B - lithological units; C - sequence stratigraphy; D - lithology; HST - highstand system tract; LST - lowstand system tract; TST transgressive system tract. Literature data comes from Coen-Aubert $(1988,1990,1992,1996,1997,1998,2008,2011)$ and Boulvain et al. (2011). 
1996 Rhytidolasma dahlmense (Haller, 1936). - Coen-Aubert, p. 26, pl. 1, fig. 8, pl. 3, figs $1-5$, pl. 4, figs $1-7$.

1997a Heliophyllum (Heliophyllum) halleri Schröder, 1995. Schröder, p. 10, pl. 2, fig. 14.

1998 Heliophyllum (Heliophyllum) halleri Schröder, 1995. Schröder, pp. 30, 31, pl. 2, figs 9, 10.

Material. - Resteigne (RES/2015.09.29/1).

Diagnosis. - See Schröder (1995a).

Description. - Specimens with 38 septa of both orders at a diameter of $37 \mathrm{~mm}$. The major septa are long but do not reach the axis of the corallum and leave a free space. The major and the minor septa are thin, bearing well-marked yardarm carinae. The minor septa are $3 / 4$ as long as the length of the major septa. The dissepimentarium comprises 16-17 rows of regular dissepiments, the outer one or two rows possess a concavity orientated outwards, in the other rows the concavity is orientated towards the axis of the corallum. There is an open, shallow cardinal fossula (Fig. $6 \mathrm{~A})$. The width of the tabularium is $17 \mathrm{~mm}$. In longitudinal section, the dissepiments are horizontal in periphery and declined towards the axis at an angle of $70^{\circ}$ (Fig. 6B). The tabulae are incomplete. There is 15 tabulae $/ \mathrm{cm}$.

Discussion. - This specimen is similar to those attributed to H. halleri Schröder, 1995 by Schröder (1995a, b, 1997a, 1998). It differs from $H$. dahlmense (Haller, 1936) by a clearly-marked recognizable fossula and a larger dissepimentarium. Moreover, the septa of $H$. halleri bear almost exclusively yardarm carinae whereas $H$. dahlmense possessed zigzag carinae (Schröder, 1995a). The thickening is more frequent, not only restricted to the center of the corallum, which clearly distinguishes this material from $H$. halli Milne-Edwards \& Haime (1850). The characters observed by Coen-Aubert (1996) in her material from Resteigne (30-47 septa of both orders, diameter of 20 to $46 \mathrm{~mm}$, septa more or less thickened in the dissepimentarium, major septa usually reaching the axis of the corallum, tabulae incomplete, minor septa just entering into the tabularium, some being contratingents, 21 to 26 rows of dissepiments, tabularium 9.7 to $23 \mathrm{~mm}$ ) are typically diagnostic for $H$. halleri as suggested by Schröder (1995a) and $H$. dahlmense sensu Birenheide (1963). Hence, we consider the Belgian material to belong to $H$. halleri rather than $H$. dahlmense.
Occurrence. - The specimen comes from the disused Resteigne quarry, from the lower part of the Hanonet Fm., in the ensensis Zone. This species is known from the upper Eifelian Freilingen Fm. of the Eifel Mountains (Schröder 1995a, b, 1997a, 1998).

\section{Genus Chostophyllum Pedder, 1982}

Type species. - Chostophyllum metula Pedder, 1982.

Diagnosis. - See Schröder (1997a).

Chostophyllum dollendorfense Schröder, 1997

Figure $6 \mathrm{~F}-\mathrm{H}$

*1997a Chostophyllum dollendorfense n. sp.; Schröder, p. 13, pl. 2, figs 20-24, text-figs 3-5.

1998 Chostophyllum dollendorfense Schröder, 1997. Schröder, p. 39, pl. 8, fig. 52.

2014b Chostophyllum cf. dollendorfense Schröder, 1997. Abbasi et al., p. 129, figs 5c, d.

Material. - Resteigne (RES I-3/12 éb., RES I-9/8, RES I-11/3, RES II-5/15, RES II-5/6 éb.).

Diagnosis. - See Schröder (1997a).

Description. - Specimens with 26 to 30 septa of both orders at a diameter of $11 \mathrm{~mm}$ to $19 \mathrm{~mm}$. The major septa almost reach the centre of the corallum but leave a free space. The septa are bent towards the cardinal fossula (Fig. 6F). The septa are commonly thickend in the tabularium. The minor septa are half as long as the length of the major septa. The dissepimentarium comprises 2 to 7 rows ( 5 on average) of regular dissepiments. The width of the tabularium is of $7.5 \mathrm{~mm}$ to $11.6 \mathrm{~mm}$. The external wall is thick, particularly in juvenile stages. In longitudinal section, the tabulae are complete, flat and evenly distributed vertically ( 8 tabulae $/ \mathrm{cm})$.

Discussion. - The specimens are identical to those attributed to the material described by Schröder (1997a, 1998) and also to the material from N Iran described by Abbasi et al. (2014b).

Occurrence. - This species is common in the whole Hanonet Fm. on both sides of the Eifelian-Givetian boundary, in Resteigne. This species is known from the upper Eifelian

Figure 5. Ptenophyllids rugose corals from the Hanonet Formation. $-A-C-$ Acanthophyllum vermiculare (Goldfuss, 1826), specimen COUV I-6/3 from Couvin, TS (A) and LS (B), specimen RES I-7/2 éb. from Resteigne, TS (C). D - Acanthophyllum radiatum (Wedekind, 1924), specimen RES I-3/13 éb. from Resteigne, TS. • E, F - Acanthophyllum heterophyllum (Milne Edwards \& Haime, 1851), specimen COUV I-4/7 from Resteigne, TS (E), specimen JML-M/1 from Jemelle, TS (F). $\bullet$ G, H - Acanthophyllum sp.1, specimen COUV I-6/12 from Couvin, TS (G) in a juvenile stage and TS $(\mathrm{H})$ in a mature stage. Magnification $\times 2$ for all specimens. 

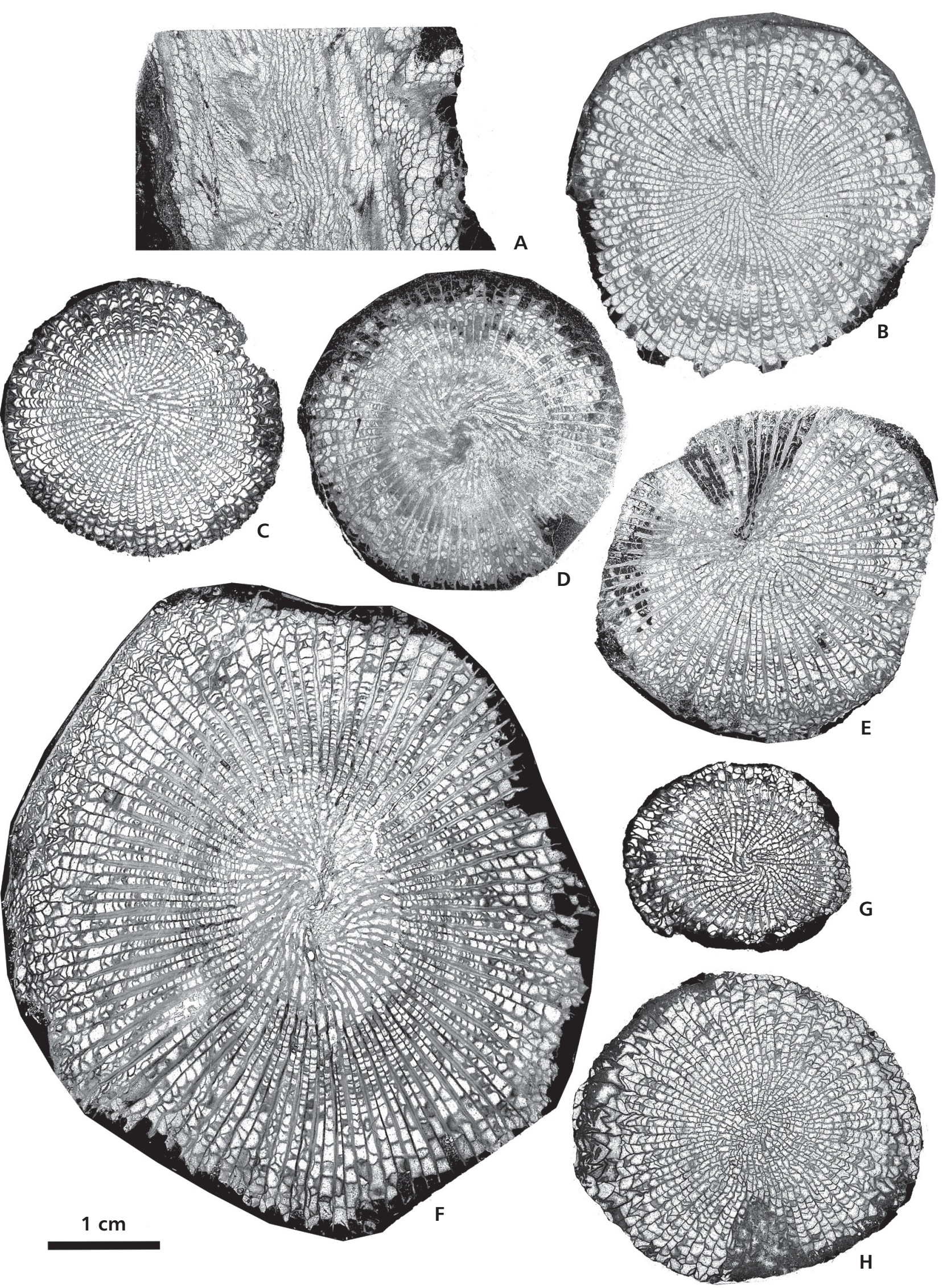
of the Eifel Mountains (Freilingen Fm.; Schröder 1997a, 1998) and the Givetian of Iran (Abbasi et al. 2014b).

Family Cyathopyllidae Dana, 1846a

\section{Genus Glossophyllum Wedekind, 1924}

Type species. - Glossophyllum dohmi Wedekind, 1924.

Diagnosis. - See Hill (1981).

\section{Glossophyllum ceratites (Goldfuss, 1826)}

Figure 6E

*1826 Cyatophyllum ceratites nobis; Goldfuss, p. 57, pl. 17, fig. 2 i.

1987 Glossophyllum ceratites - Lütte, p. 441, pl. 4, figs 16, 17, pl. 5, figs 18-22, pl. 6, figs 24, 25, pl. 7, fig. 28. [cum syn.]

? 1998 Glossophyllum sp. cf. ceratites (Goldfuss, 1826). Schröder, pp. 32, 33, pl. 3, fig. 12.

1999 Glossophyllum ceratites (Goldfuss, 1826). - Schröder \& Kazmierczak, p. 99, pl. 2, fig. 6.

2014a Glossophyllum ceratites (Goldfuss, 1826). - Abbasi et al., pp. 12, 13, pl. 2, fig. 5.

Material. - Resteigne (RES II-5/4 éb.).

Diagnosis. - See Birenheide (1978).

Description. - Specimen having 38 septa of both orders at a diameter of $26 \mathrm{~mm}$. The major and the minor septa are of a similar thickness (Fig. 6E). The major septa are long but do not reach the axis of the corallum and leave a free space. The minor septa are $3 / 4$ as long as the major septa and cross the entire dissepimentarium. The wall is slightly thickened. The dissepimentarium comprises $7-8$ rows of regular concentric dissepiments. The tabularium is $16 \mathrm{~mm}$-wide.

Discussion. - This single specimen fits the definition of G. ceratites and is very similar to the specimens attributed to Ceratophyllum ceratites by Tsien (1969), Birenheide (1978), Lütte (1987), Schröder (1998), Schröder \& Kazmierczak (1999) and Abbasi et al. (2014a); see Schröder (1998) for further discussion on this species.
Occurrence. - The specimen comes from the lower part of the Hanonet Fm. (ensensis Zone) in the Resteigne section. This species is known from the upper Eifelian to the lower Givetian of the Eifel Mountains (Freilingen, Loogh and Cürten formations) (Birenheide 1978, Lütte 1987, Schröder 1998). Outside Europe, this species has been identified in the lower Givetian of Eastern Albroz Mountains (Kosheyilagh Formation) in NE Iran (Abbasi et al. 2014a) and Morocco (Ouihalane "coral reef", E AntiAtlas, Schröder \& Kazmierczak 1999).

\section{Genus Spinophyllum Wedekind, 1922}

Type species. - Campophyllum spongiosum Schlüter, 1889.

Diagnosis. - See Hill (1981).

\section{Spinophyllum incompositum Schröder, 1997}

Figure 6C, D

*1997a Spinophyllum incompositum n. sp.; Schröder, p. 9, pl. 1, figs 6-13.

1998 Spinophyllum incompositum Schröder, 1997. Schröder, p. 37, pl. 4, figs 30, 31.

Material. - Resteigne (RES I-3/5 éb., RES I-3/14 éb.).

Diagnosis. - See Schröder (1997a).

Description. - Specimens with 30 to 33 septa of both orders at a diameter of $16 \mathrm{~mm}$ to $22 \mathrm{~mm}$. The septa are commonly carinate and spindle-shaped thickened in the dissepimentarium and thinner in the the tabularium (Fig. 6C). The major septa are long but do not reach the axis of the corallum and leave a free space in the centre. The minor septa are half as long as the major septa and they are restricted to the dissepimentarium. The wall is thickened. The dissepimentarium includes 5 to 8 rows of regular dissepiments, the inner row being thickenend by a stereoplasmic deposit. The width of the tabularium varies from $8.2 \mathrm{~mm}$ to $11.5 \mathrm{~mm}$.

Discussion. - The specimens are similar to the type material described by Schröder (1997a, 1998).

Figure 6. Heliophyllid, siphonophrentid and cyathophyllid rugose corals from the Hanonet Formation. • A, B - Heliophyllum halleri Schröder, 1995, specimen RES/20150929/1 from Resteigne [A in longitudinal section (LS), B in transverse section (TS)]. • C, D - Spinophyllum imcompositum Schröder, 1997, specimen RES I-3/5 éb. from Resteigne, TS (C), specimen RES II-9/17 from Resteigne, TS (D). • E - Glossophyllum ceratites (Goldfuss, 1826), specimen RES II-5/4 éb. from Resteigne TS. • F-H - Chostophyllum dollendorfense Schröder, 1997, specimen RES I-3/12 éb. from Resteigne, TS (F), specimen RES I-9/8 from Resteigne, TS (G), specimen RES I-11/3 from Resteigne, TS (H). $・$ I, J - Cyathophyllum dianthus (Goldfuss, 1826), specimen 2015.10.13/09 from Couvin TS (I-J); I - transverse section showing offsets. Magnification $\times 2$ for all specimens. 

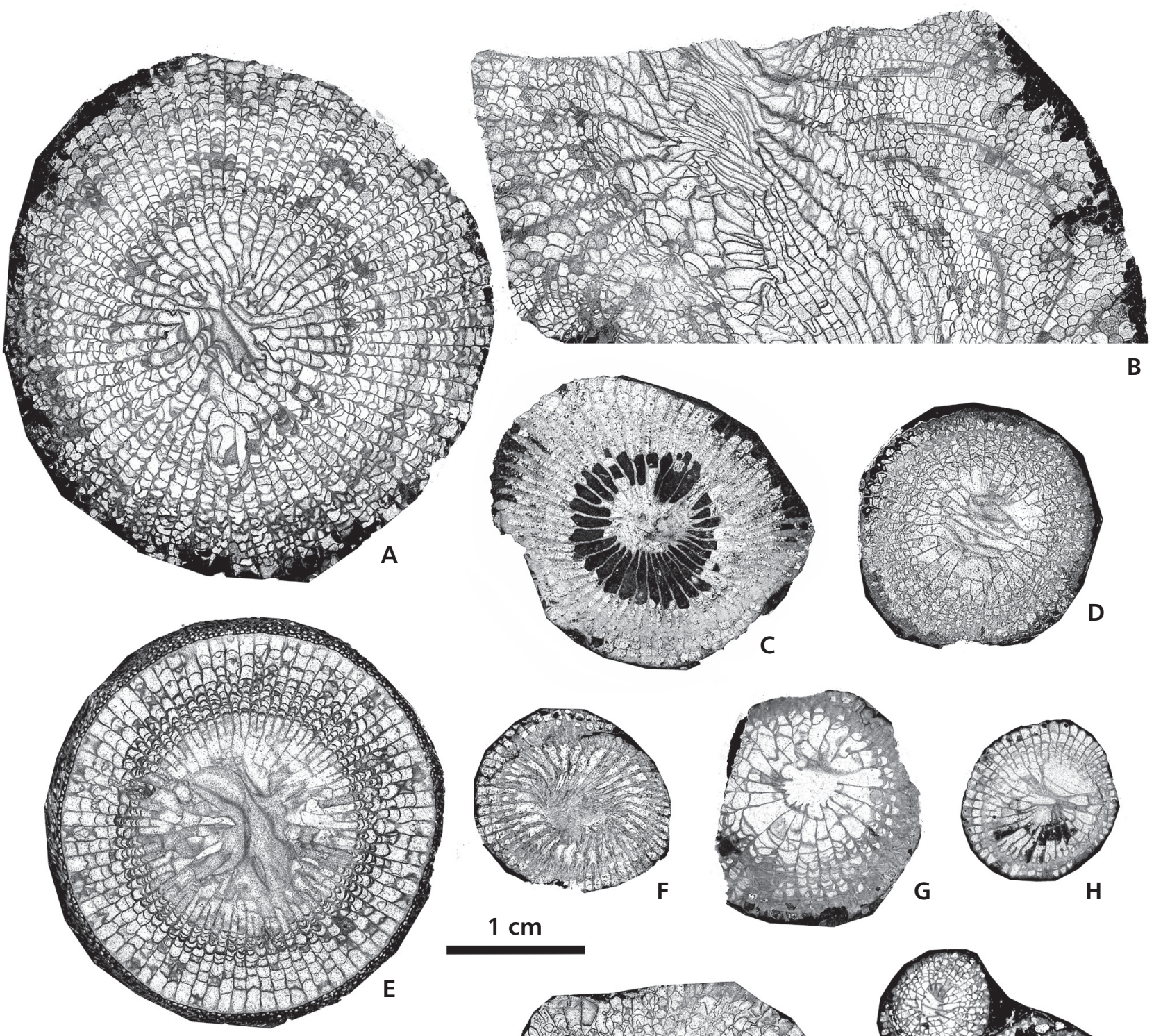

B
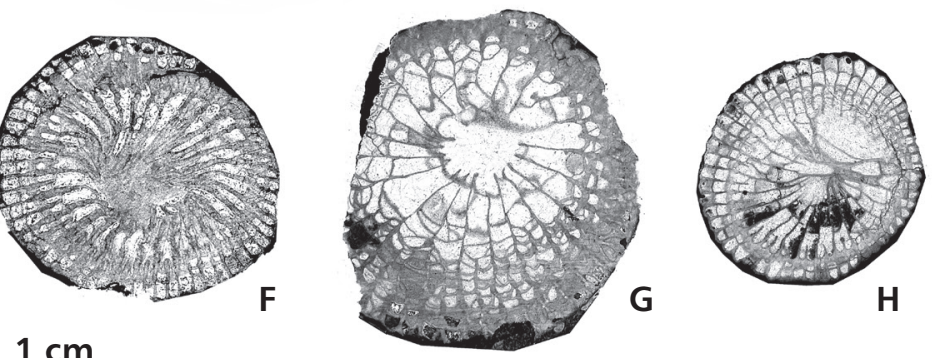

\section{$1 \mathrm{~cm}$}
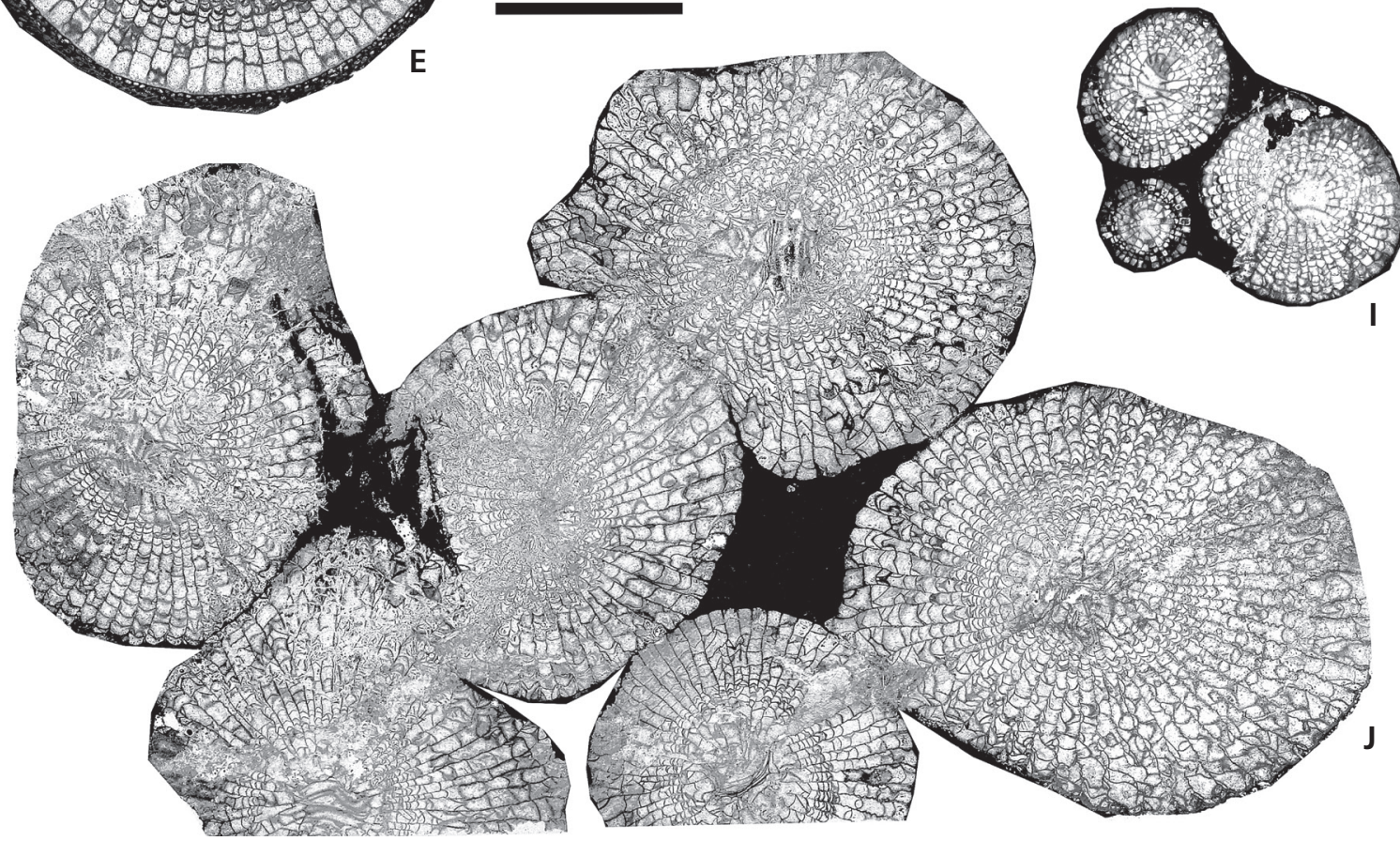
Occurrence. - The specimens come from the lower part of the Hanonet Fm. (ensensis Zone) of Resteigne. This species is known from the upper Eifelian Eilenberg $\mathrm{Mb}$. (lower part of the Freilingen Fm.) in the Eifel Mountains and, more generally, from the upper Eifelian to Givetian of Eurasia (Schröder 1997a, 1998).

Family Siphonophrentidae Merriam, 1974a

\section{Genus Enallophrentis Oliver, 1993}

Type species. - Strombodes simplex Hall, 1843.

Diagnosis. - See Oliver (1993).

\section{Enallophrentis martinae (Coen-Aubert, 1996)} Figure $7 \mathrm{~K}-\mathrm{M}$

1995b Enallophrentis n. sp.; Schöder, p. 380, pl. 1, figs 1, 2. *1996 Breviphrentis martinae n. sp.; Coen-Aubert, p. 24, pl. 1, figs 1-5, pl. 2, figs 1-3.

1996 Enallophrentis rhenana n. sp.; Schröder et al., pp. 18, 19, pl. 1, figs $1-3$, pl. 2, figs 4-8, pl. 3, figs 9-14, pl. 4, figs $15-18$.

Material. - Resteigne (RES I-2/2, RES I-3/1 éb., RES I-3/7 éb.).

Diagnosis. - See Coen-Aubert (1996).

Description. - Specimens with 36 to 54 septa of both orders at a diameter of $25 \mathrm{~mm}$ to $40 \mathrm{~mm}$. The major septa almost reach the centre of the corallum but leave a free space. The major septa are commonly thickened and their axial ends are commonly curled (see also Coen-Aubert 1996, pl. 2, fig. 4) in a poorly defined axial structure. The minor septa are half as long as the major septa. The cardinal fossula is conspicuous in juvenile stages (Fig. 7M) but tends to be less deep in more advanced stages of growth (Fig. 7K, L). The bilateral symmetry is variabily marked. The external wall is up to $2.2 \mathrm{~mm}$-thick. In longitudinal section, the tabulae are complete or irregularly divided, commonly convex with the axial part domed and the lateral part forming a peripheral gutter.

Discussion. - Coen-Aubert (1996) described from Resteigne Breviphrentis martinae. However, Pedder (2002) and Wrzołek (2002) challenged the generic attribution regarding the lack of calicinal expansions and axially thickened bifurcated and twisted long major septa almost forming an axial structure with the domed tabulae. Together with the thick stereozone and bilateral symmetry materialised by the cardinal fossula and a trochoid habitus, these characters suggest a generic attribution to
Enallophrentis Oliver, 1993 rather than Breviphrentis. Almost simultaneously Schröder et al. (1996) introduced Enallophrentis rhenana based on material from the upper Eifelian Freilingen Fm. of the Eifel Mts which, compared to Coen-Aubert's species, is slightly larger $(34-50 \mathrm{~mm}$ in diameter and 49-58 septa of both orders). However E. martinae (Coen-Aubert, 1996) topotypes show that the range of this species is wider than the original material and covers the same area of variation than E. rhenana (Schröder et al., 1996), with the same thickened stereozone, long minor septa, twisted and thickened axial ends of the major septa and a cardinal fossula. Being moreover of the same age (ensensis conodont Zone), we consider E. rhenana and E. martinae to be synonymes. E. martinae being published earlier (June 1, 1996) than the German species (July 31, 1996), it has the priority. From the Polish early Givetian species E. corniformis (Gürich, 1896) that display similar size and number of septa (35-50 septa of both orders at $19-48 \mathrm{~mm}$ in diameter after Wrzołek 2002), it differs by longer minor septa and the limited development of thickening in early stages. The late Eifelian-early Givetian form ?E. sp. described by Schröder \& Kazmierczak (1999) from the Ouihalane reef of Morocco differs by the dilatation of the septa limited in the cardinal quadrants.

Occurrence. - Enallophrentis martinae (Coen-Aubert, 1996) occurs in the late Eifelian (ensensis conodont Zone) Hanonet Fm. of S Belgium and Freilingen Fm. of the Eifel Mts (Schröder et al. 1996).

Family Phillipsastreidae Roemer, 1883

\section{Genus Macgeea Webster, 1889}

Type species. - Pachyphyllum solitarium Hall \& Whitfield, 1873.

Diagnosis. - See Coen-Aubert \& Wrzołek (1991).

\author{
Macgeea bathycalyx (Frech, 1886) \\ Figure $8 \mathrm{H}$ \\ e.p. *1886 Cyathophyllum bathycalyx n. sp.; Frech, pp. 181, 182, \\ pl. 19, figs 8-11, (non pl. 17, figs 17-24). \\ 1996 Macgeea bathycalyx bathycalyx (Frech, 1886). - Schrö- \\ der, p. 55, pl. 1, figs 1-8, pl. 2, figs 9-17. [cum syn.]
}

Material. - Resteigne (RES II-8/7) and Couvin (COUV I-2/1, COUV I-6/14).

Diagnosis. - See Birenheide (1978).

Description. - Specimens with 28 to 33 septa of both orders (30 on average) at a diameter of $13 \mathrm{~mm}$ to $19 \mathrm{~mm}$ 


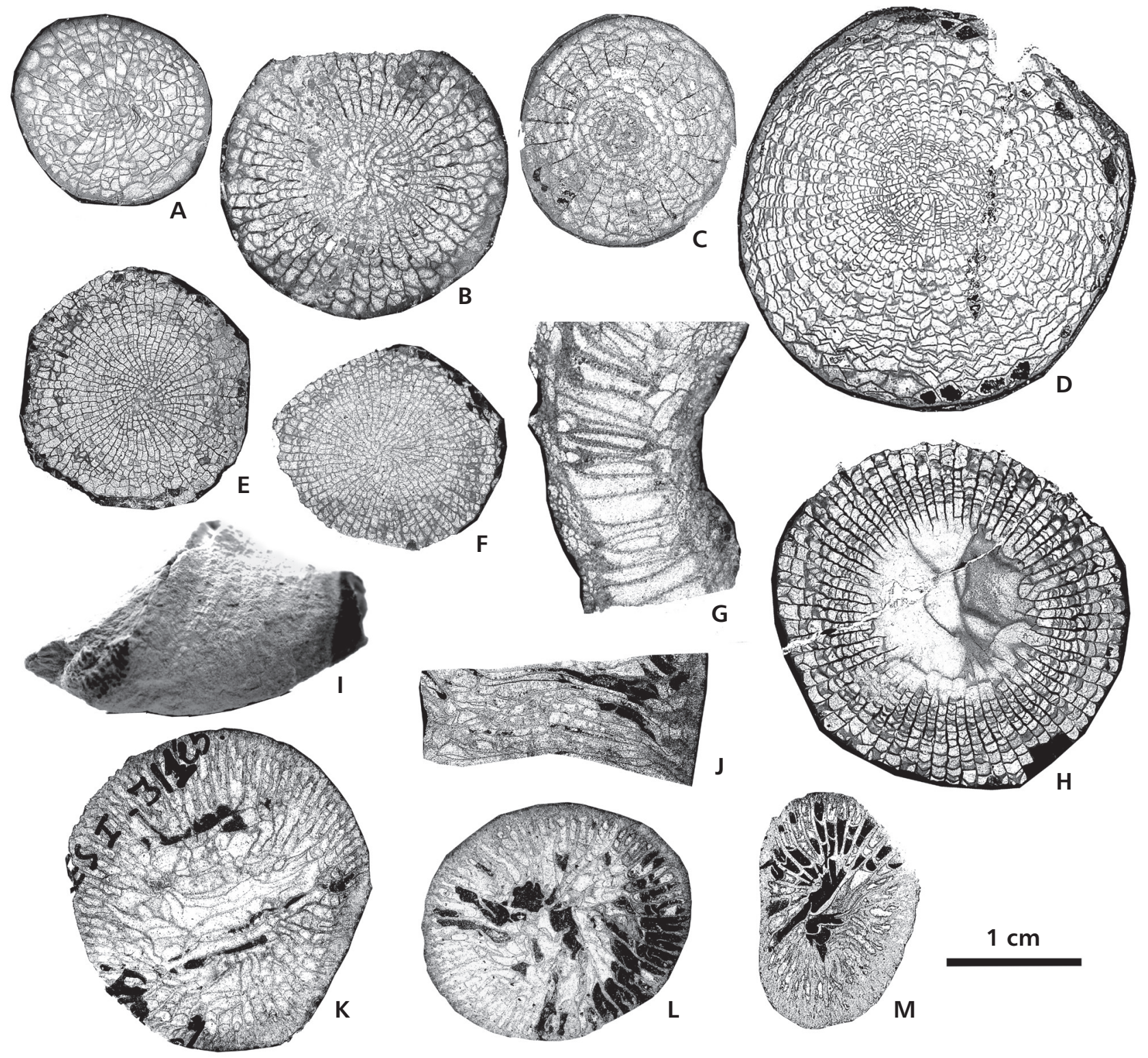

Figure 7. Ptenophyllid, dysphyllid, goniophyllid and zaphrentid rugose corals from the Hanonet Formation. • A-C - Grypophyllum cf. denckmanni Wedekind, 1922, specimen NIS-Est/4 from Nismes, TS (A), specimen COUV I-5/1 éb. from Couvin, TS (B) transverse section, specimen COUV I-6/11 from Couvin, TS (C). • D - Grypophyllum sp., specimen WLM/37b from Wellin, TS. • E, F - ?Grypophyllum sp., specimen COUV I-6/6 from Couvin, TS (E), specimen RES II-9/15 from Resteigne, TS (F). G, H - Aristophyllum luetti Coen-Aubert, 1997, specimen JML-M/2 from Jemelle, TS (G), specimen RES I-9/6 from Resteigne, LS (H). - I - Calceola sandalina (Linnaeus, 1771), specimen from Resteigne disused Quarry, unit 5, lateral view. $\cdot$ J-M - Enallophrentis martinae (Coen-Aubert, 1996), specimen RES I-3/7 éb. from Resteigne, LS (J) and TS (K), specimen RES I-3/1 éb. from Resteigne TS (L) and specimen RES I-2/2, in a juvenile, from Resteigne TS (M). Magnification $\times 2$ for all specimens.

(15 $\mathrm{mm}$ on average). The major septa are long but do not reach the axis of the corallum and leave a free space. Both orders of septa are thickened especially over the horseshoes dissepiments. The minor septa are half as long as the major septa and confined to the dissepimentarium. The dissepimentarium typically consists of 2 rows of thickened regular concentric dissepiments, the external row with the concavity oriented towards wall whereas the inner row has the concavity towards the axis, the opposite directions of concavity witness the intersection of the horseshoe dissepiments by the transverse section (Fig. 8H). The width of the tabularium varies from $9.8 \mathrm{~mm}$ to $12.8 \mathrm{~mm}$. In longitudinal section, the dissepiments are horizontal near the wall and are inclined at an angle up to $45^{\circ}$ in the inner rows. The tabulae are complete, subhorizontal and there are $14-16$ tabulae $/ \mathrm{cm}$. 
Discussion. - With an average diameter of $15 \mathrm{~mm}$ for 30 septa of both orders, this material is similar to the specimens attributed to Macgeea bathycalyx by Tsien (1969), Birenheide (1978) and Schröder (1995a, 1996). The colonial faciculate phillipsastreid Thamnophyllum occlusum (Tsien, 1969) occurring also in the same strata displays a very similar morphology but isolated corallites can be distinguished from small-sized sections of $M$. $b a$ thycalyx by a higher ratio of number of septa diameter.

Occurrence. - This species occurs at Couvin and Resteigne, in the entire Hanonet Fm., below and above the Eifelian-Givetian boundary. Macgeea bathycalyx is known from the upper Eifelian and lower Givetian of the Eifel Mountains (Junkerberg, Freilingen and Ahbach formations) (Birenheide 1978, Schröder 1996).

Family Ptenophyllidae Wedekind, 1923

\section{Genus Dohmophyllum Wedekind, 1923}

Type species. - Dohmophyllum involutum Wedekind, 1923.

Diagnosis. - See Pedder in Pedder et al. (1971).

\section{Dohmophyllum aff. difficile (Wedekind, 1925)}

Figure 9D, E

1998 Dohmophyllum sp. cf. difficile (Wedekind, 1925). Schröder, p. 55, pl. 12, figs 77, 78.

Material. - Couvin (COUV I-4/6, COUV I-6/5, COUV I-6/5, COUV I-7/4) and Nismes (NIS-Est/5, NIS-Est/8, NIS-Est/14, NIS-Ouest/4).

Description. - Specimens with 29 to 36 septa of both orders (31 on average) at a diameter of $17 \mathrm{~mm}$ to $42 \mathrm{~mm}$ (25-30 mm commonly). The major and the minor septa are of similar thickness and bear some carinae in the tabularium. The major septa reach usually the axis of the corallum where they are twisted to form a vortex (Fig. $9 \mathrm{D}, \mathrm{E}$ ). The minor septa are generally long (up to $90 \%$ of the length of the major septa). The dissepimentarium includes 13 to 22 rows (18 on average) of concentric or angulo-concentric interseptal dissepiments, the external row occasionnaly displaying flat dissepiments. The width of the narrow tabularium varies from $5.8 \mathrm{~mm}$ to $13.7 \mathrm{~mm}$.

Discussion. - The specimens are slightly smaller (25$30 \mathrm{~mm}$ of diameter) than those identified by Birenheide (1963) (25-60 $\mathrm{mm}$ with a mean value of $40 \mathrm{~mm}$ ), Birenheide (1978) (40-45 mm) and Schröder (1998) (45 mm). Nevertheless the number of septa of the analysed specimens ( 31 to 32 of both orders) is similar to the number observed by Birenheide (1978) ( 32 to 34 of both orders) and Schröder (1998) (30 to 40 of both orders). The tabularium width $(5.8-13.7 \mathrm{~mm})$ is similar to the one observed by Birenheide (1963) $(\sim 10 \mathrm{~mm})$ and Schröder (1998) (5-14 mm). This species differs from Dohmophyllum wedekindi by the presence of a more or less pronounced vortex.

Occurrence. - This species was identified at Couvin and Nismes, in the middle and upper parts of the Hanonet Fm., in the hemiansatus Zone. D. difficile and similar species (e.g. D. cf. difficile in Schröder 1998) is known from the Eifelian and the Givetian of the Eifel Mountains (Nohn up to Dreimühlen formations) and Sauerland (Oberhonseler Fm.; Birenheide 1963, 1972, 1978; Schröder 1998).

\section{Dohmophyllum wedekindi Birenheide, 1972}

Figure 9B, C

1925 Pseudoptenophyllum sp. - Wedekind, pl. 16, figs 95, 96.

*1972 Dohmophyllum weidekindi n. sp.; Birenheide, pp. 422-424, text-figs 9-13.

1978 Dohmophyllum wedekindi (Birenheide, 1972). Birenheide, pp. 142, 146, text-fig. 89.

Material. - Couvin (COUV I-6/1).

Diagnosis. - See Birenheide (1978).

Description. - Specimens having 26 septa of both orders at a diameter of $33 \mathrm{~mm}$. The minor and the major septa are of a similar thickness. The major septa reach the axis of the corallum where they are twisted and form a weak vortex. The minor septa are $3 / 4$ as long as the length of the major septa. The dissepimentarium includes 16 to 18 rows of dissepiments. The outer dissepimentarium comprises some narrow lonsdaleoid and regular concentric interseptal dissepiments whereas the inner dissepimentarium comprises angulo-concentric, herringbone and arched dissepiments (Fig. 9B). The tabularium is narrow $(8.8 \mathrm{~mm}$ in diameter).

Discussion. - This specimen is similar (26 septa of both orders at a diameter of $33 \mathrm{~mm}$ ) to the ones discribed by Birenheide (1972) (27 septa of both orders at a diameter of $25 \mathrm{~mm}$ ) and Birenheide (1978) (26 to 28 septa of both orders at a diameter varying from $25 \mathrm{~mm}$ to $35 \mathrm{~mm}$ ). This species differs from Dohmophyllum aff. difficile by the weakly pronounced vortex and the more complex composition of the dissepimentarium that includes lonsdaleoid dissepiments.

Distribution. - The specimen is from the upper part of the Hanonet Fm. (hemiansatus Zone) in the Couvin section. 

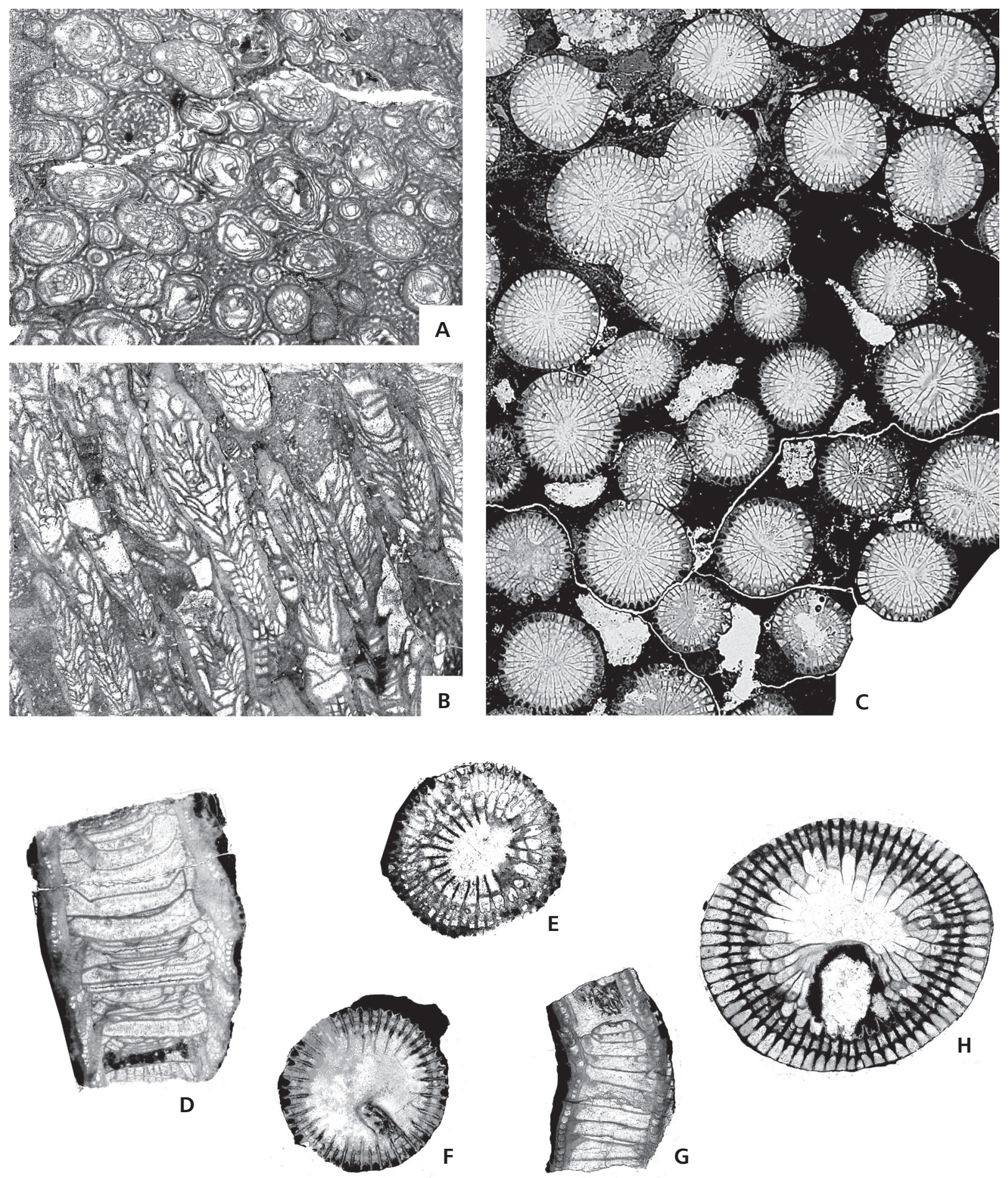

$1 \mathrm{~cm}$

Figure 8. Ptenophyllid and philipsastreid rugose corals from the Hanonet Formation. • A, B - Neomphyma dalcqae Coen-Aubert, 1992, specimen BZ-1 from Baileux zoning, TS (A) and LS (B). $・$ C-G - Thamnophyllum occlusum (Tsien, 1969), specimen Couvin 10 from Couvin, TS (C), specimen COUV I-5/5 from Couvin, LS (D) and TS (E), specimen RES II-9/1 from Resteigne, TS (F), specimen COUV I-6/8 from Couvin, TS (G). $\bullet \mathrm{H}-$ Macgeea bathycalyx (Frech, 1886), specimen COUV I-2/1 from Couvin, TS. Magnification $\times 3$ for all specimens. 
Birenheide $(1972,1978)$ identified this species in the Givetian (Loogh Fm.) of the Eifel Mountains (W Germany).

Family Stringophyllidae Wedekind, 1925

\section{Genus Stringophyllum Wedekind, 1922}

Type species. - Stringophyllum normale Wedekind, 1922.

Diagnosis. - See Coen-Aubert (2011).

\section{Stringophyllum acanthicum (Frech, 1885)}

Figure 10A, B

*1885 Endophyllum acanthicum nov. sp.; Frech, p. 929, pl. 41, fig. 5.

2011 Stringophyllum acanthicum (Frech, 1885). - CoenAubert, p. 31, pl. 1, figs 1-6, pl. 2, figs 8, 9, pl. 3, fig. 4. [cum syn.]

Material. - Nismes (NIS-Est/3, NIS-Est/13).

Diagnosis. - See Coen-Aubert (2011).

Description. - Specimens with 46 to 48 septa of both orders at a diameter of 27 to $31 \mathrm{~mm}$. The septa are commonly dilated in the tabularium. The major septa almost reach the axis of the corallum where they usually join in irregular bundles, highlighting the bilateral symmetry (Fig. 10A, B). The minor septa are $2 / 3$ to $4 / 5$ as long as the length of the major septa and are confined to the dissepimentarium where they are commonly discontinuous with isolated septal crest on the dissepiments. The wall is thickened. The dissepimentarium comprises 6-7 rows of interseptal, regular concentric and oblique dissepiments, the outer row being made of large flat lonsdaleoid dissepiments. The width of the tabularium varies from 8.3 to $9.3 \mathrm{~mm}$.

Discussion. - The present specimens have a size and a number of septa very similar to those of specimens attributed to $S$. acanthicum by Kettnerová (1932), LeMaître (1947), Tsien (1969), Birenheide (1978), Schröder (1995a, b, 1997c, 1998) and Coen-Aubert (2011). This species differs from Stringophyllum buechelense by the presence of strongly thickened major septa and the larger size of the corallum $(30 \mathrm{~mm}$ for the present species versus $20 \mathrm{~mm}$ for S. buechelense).

Occurrence. - The two specimens come from the disused Nismes quarry exposing the Givetian part of the Hanonet Fm. This species is known from the upper Eifelian and the lower Givetian (Ouihalane "coral reef") of Moroccan Ma'der Basin (LeMaître 1947, Coen-Aubert 2011), in the upper Eifelian and the Givetian of the Eifel Mountains, in the Nims $\mathrm{Mb}$. (upper part of the Jurkerberg Fm.), the Freilingen Fm., the Cürten Fm. and the Rodert Fm., Sauerland (W Germany) in the Schwelm Fm., Belgium (uppermost part of the Jemelle Fm. up to the lower part of the Trois-Fontaines Fm., Coen-Aubert 2011), England and France (Chalonnes Fm. of Brittany, Coen-Aubert 2011) (Birenheide 1978; Schröder 1995a, 1997c, 1998), in the Givetian of Moravia (Czech Republic, Kettnerová 1932) and possibly also in Russia (Urals, Shurigina 1972).

\section{Stringophyllum buechelense (Schlüter, 1889)}

Figure $10 \mathrm{C}-\mathrm{G}$

*1889 Spongophyllum buechelense Schlüter; Schlüter, p. 63, pl. 7, fig. 8.

2005 Stringophyllum buechelense (Schlüter, 1889). Schröder, p. 102, pl. 10, figs 9-12. [cum syn.]

Material. - Resteigne (RES indét., RES I-8/2 éb.+ pl. d, RES II-9/10, RES II-9/16 a-b et c, RES II-9/19), Couvin (COUV I-6/13, COUV I-7/1) and Nismes (NIS-Est/16).

Diagnosis. - See Birenheide (1978).

Description. - Specimens with 32 to 40 septa of both orders at a diameter of $19 \mathrm{~mm}$ to $24 \mathrm{~mm}$. The septa are slightly dilated. The major septa almost reach the axis of the corallum where they are usually joined in irregular bundles, highlighting the bilateral symmetry (Fig. 10D). The minor septa are $2 / 3$ as long as the length of the major septa and are confined to the dissepimentarium where they are commonly discontinuous. The wall is thickened. The dissepimentarium comprises 4 to 13 rows (commonly 6 to 9) of transeptal, regular and herringbone dissepiments, the outer row comprising large and flat lonsdaleoid dissepiments. The width of the tabularium varies from $4.1 \mathrm{~mm}$ to $8.7 \mathrm{~mm}$. In longitudinal section, the dissepiments are inclined at an angle of $45-50^{\circ}$ towards the tabularium (Fig. 10C, F). The tabulae are almost complete and slightly depressed axially. There are 18-27 tabulae/cm.

Discussion. - As the present specimens have a size and a number of septa very similar to those of $S$. buechelense, e.g. in LeMaître (1947), Tsien (1969), Schröder (1995a, 2005) and Schröder \& Kazmierczak (1999), they are confidently attributed to this species. However, the specimens figured by Birenheide (1978) and May (1993) display a larger tabularium (1/2 of the corallum diameter) despite a similar number of septa.

Distribution. - This species is present in Couvin, Nismes and Resteigne, in the middle and upper parts of the Hanonet Fm., above the Eifelian-Givetian boundary. The species is 

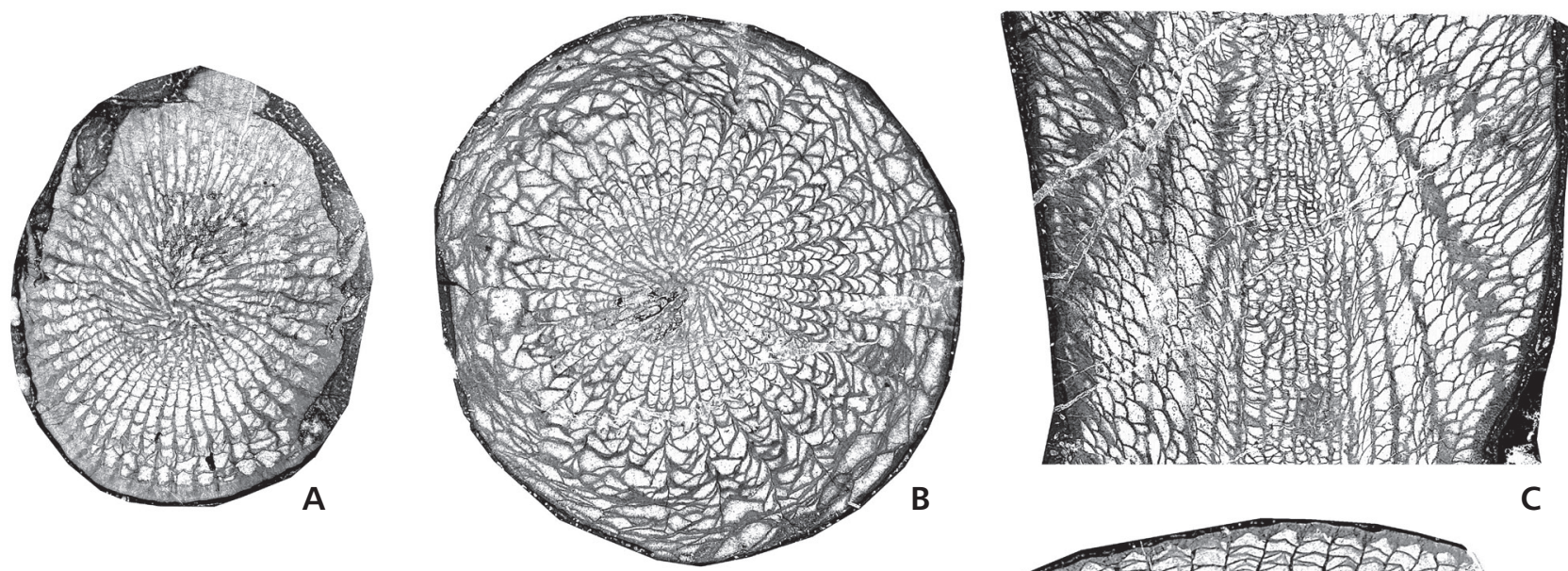

\section{C}
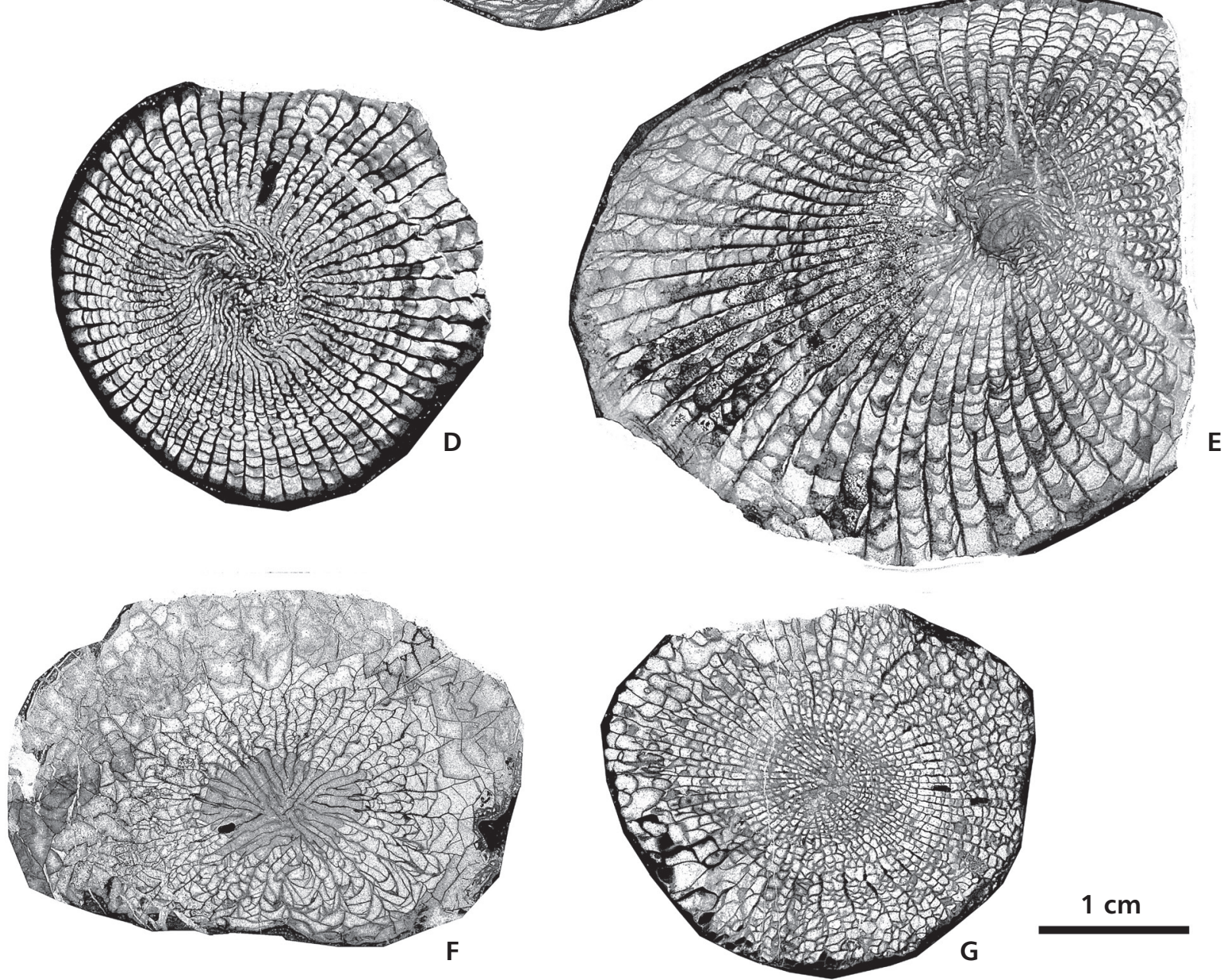

Figure 9. Ptenophyllid rugose corals from the Hanonet Formation. - A - Acanthophyllum sp. 2, specimen NIS-Est/12 from Nismes, TS. • B, C Dohmophyllum wedekindi Birenheide, 1972, specimen COUV I-6/1 from Couvin, TS (B) and LS (C). D, E - Dohmophyllum aff. difficile (Wedekind, 1925), specimen NIS-Est/8 from Nismes, TS (D), specimen NIS-Est/5 from Nismes, TS (E). • F, G - Dohmophyllum sp., specimen NIS-Est/17 from Nismes, TS (F) transverse section, specimen COUV I-4/3 from Couvin, TS (G). Magnification $\times 2$ for all specimens.

known from the Eifelian and Givetian of W Germany in the Sauerland (Bredenburch Mb. of the Unterhonsel Fm. and in the Oberhonseler Fm.) and in the Eifel Mountains (Cürten and Kerpen formations) and also in France,
Poland, England (Joseph \& Tsien 1975; Birenheide 1978; May 1993; Schröder 1995a, 2005). This species is also known from the lower Givetian of the eastern Anti-Atlas (Ouihalane "coral reef") in Morocco (LeMaître 1947, 
Schröder \& Kazmierczak 1999) and in the lower Givetian strata of E Australia (described as S. irregulare Hill, 1942).

Family Pycnostylidae Stumm in Shrock \& Twenhofel (1953)

\section{Genus Cyathopaedium Schlüter, 1889}

Type species. - Calophyllum paucitabulatum Schlüter, 1880.

Diagnosis. - See Hill (1981).

\section{Cyathopaedium paucitabulatum (Schlüter, 1880)}

Figure 11L-N

*1880 Calophyllum paucitabulatum sp. n.; Schlüter, p. 52.

? 1885 Amplexus multiseptatus n.; Maurer, p. 84, pl. 1, figs 11-18.

1894 Coelophyllum paucitabulatum Schlüter. - Weissermel, p. 636, text-fig 1.

1883 Calophyllum radicans n. Schulz; Schulz, p. 74, pl. 21, figs 1-4.

1969 Amplexus champernownei Smith \& Thomas, 1963.Tsien, p. 145, pl. 22, figs 1, 2.

1978 Cyathopaedium paucitabulatum (Schlüter, 1880). Birenheide, pp. 186, 187, pl. 21, fig. 2.

2002 Cyathopaedium sp. - Schröder, pp. 178, 180, pl. 1, figs $1-9$, pl. 2, fig. 11.

Material. - Resteigne (RES I-6/1, RES II-5/1, RES II-5/4, RES II-5/5, RES II-5/6 a-e, RES II-5/17).

Diagnosis. - See Birenheide (1978).

Description. - Specimens with a diameter of $11 \mathrm{~mm}$ to $22 \mathrm{~mm}$. There are $<60$ very rudimentary septa (Fig. $11 \mathrm{M}$ ), where developed and thickened in continuity with the wall, stereoplasma commonly filling the interseptal loculi. The thickness of the wall varies from 0.5 to $2.2 \mathrm{~mm}$. The wall is festooned internally (Fig. 11L). The tabulae are subhorizontal or infundibuliform, vesicular and irregularly space $(2-5 \mathrm{~mm}$ between individual tabula) (Fig. $11 \mathrm{~N})$.

Discussion. - The genus Cyathopaedium - together with Stylopleura, Fletcheria, Maikottia and Pycnostylus are based on morphologically simple species displaying calinical buddings, short undifferenciated septa confined to the wall, widely-spaced tabullae and no dissepimentarium (Pedder 1976, Schröder 2007). Their very simple morphology makes them similar and without a revision of these forms (including habitus), synonymy can not be discarded. However, with its long cylindrical corallites, the present specimens ressemble material attributed to Cyathopaedium Schlüter, 1880 which differs from Stylopleura Merriam, $1974 \mathrm{~b}$ by its habitus (the American genus displaying ceratoid or subcylindrical corallites). Birenheide (1978) recognized two different species in the genus Cyathopaedium: C. paucitabulatum (Schlüter, 1880) with 48 septa at a diameter of 25 to $40 \mathrm{~mm}$ and tabulae spaced $25-30 \mathrm{~mm}$ apart, and C. radicans (Schulz, 1883) with 60 septa at a diameter of 30 to $50 \mathrm{~mm}$ and tabulae spaced by $c .1 \mathrm{~cm}$. However, in the present material, there is a continuum variation from small individuals to large ones, with no discrete boundary or differences in characters. Keeping in mind that these corals are very simple and morphologically malleable, it would seem suitable to group all individuals in a single species under the name C. paucitabulatum Schlüter, 1880. Schröder (2002) suggested that several species described under the generic name Amplexus in the Devonian of Germany might also be representants of Cyathopaedium but without a carefull revision, notably of the ontogeny of the material, their synonymy remains hypothetical.

Occurrence. - This species is present at Resteigne, in the lower and middle parts of the Hanonet Fm., below and above the Eifelian-Givetian boundary. The species C. paucitabulatum is known from the Givetian of W Germany (Büchel Fm.) whereas the species $C$. radicans is known from the Givetian of the Eifel Mountains (from Loogh to Dreimühlen formations) (Birenheide 1978).

Family Tryplasmatidae Etheridge, 1907

\section{Genus Tryplasma Lonsdale, 1845}

Type species. - Tryplasma aequabile Lonsdale, 1845.

Diagnosis. - See Glinski (2001).

Tryplasma rohrense Glinski, 2001

Figure 11I-K

* 2001 Tryplasma rohrensis n. sp.; Glinski, p. 74, figs 1-14, 16.

Figure 10. Stringophyllid rugose corals from the Hanonet Formation. • A, B - Stringophyllum acanthicum (Frech, 1885), specimen NIS-Est/3 from Nismes, TS (A), specimen NIS-Est/13 from Nismes, TS (B). • C-G - Stringophyllum buechelense (Schlüter, 1889), specimen RES II-9/16 from Resteigne, TS (C) and LS (D), specimen NIS-Est/16 from Nismes, TS (E) and LS (F), specimen RES II-9/10 from Resteigne, TS (G). • $\mathrm{H}-$ Sociophyllum torosum (Schlüter, 1881), specimen Couvin 22e from Couvin, TS. Magnification $\times 2$ for all specimens. 

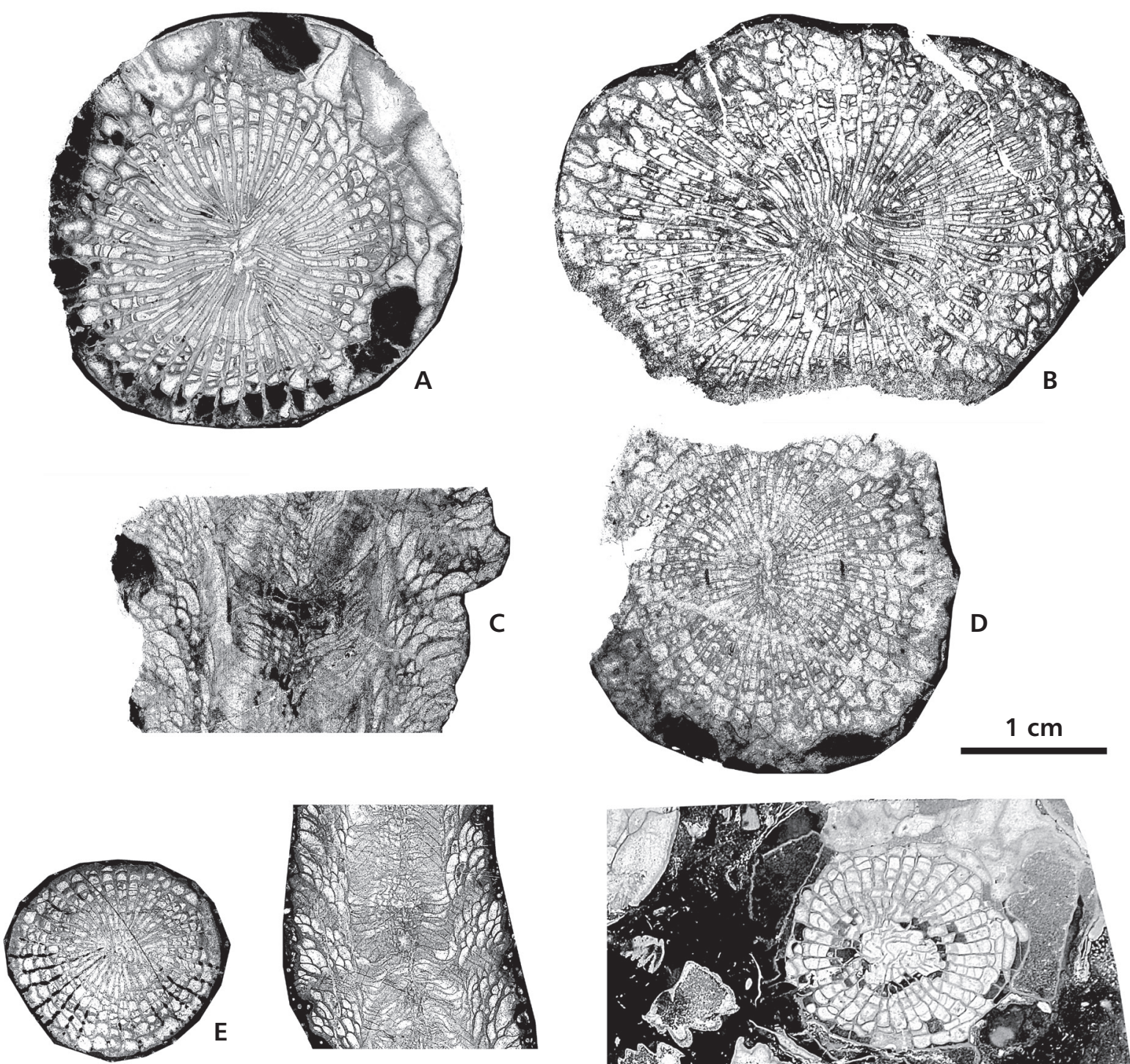

$\mathbf{F}$

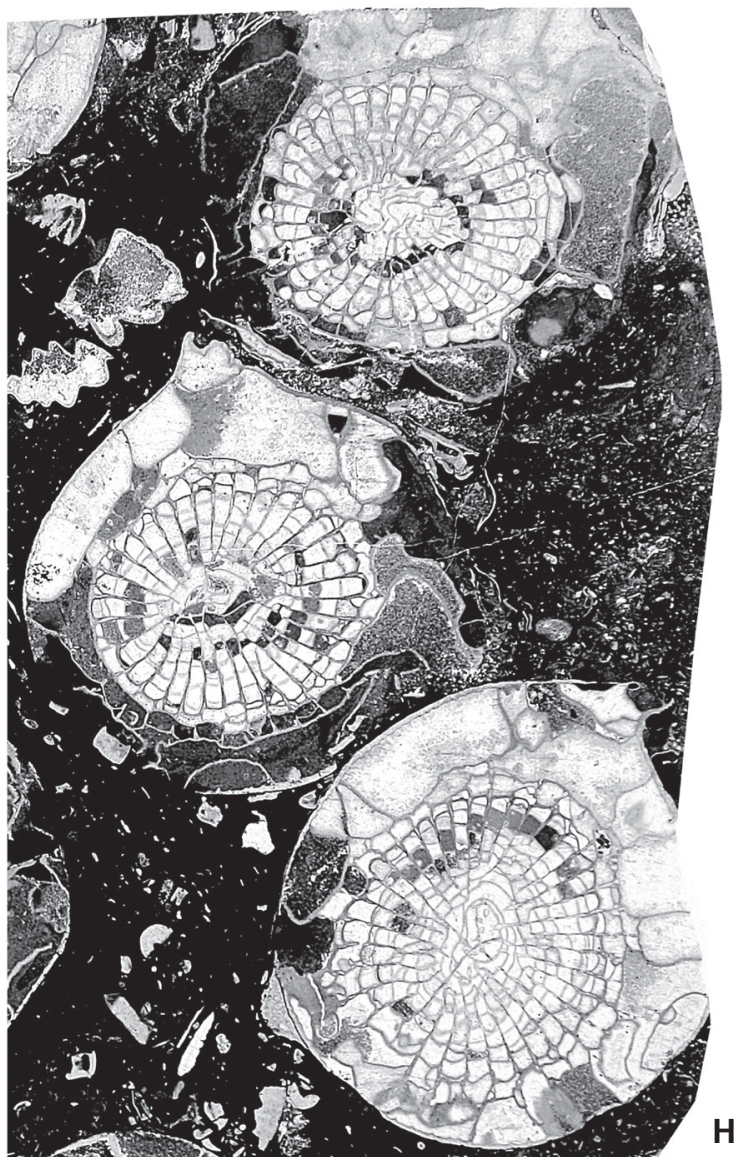


Material. - Resteigne (RES II-5/6 f-h), Baileux (BAI-1) and Couvin (Couvin/17).

Diagnosis. - See Glinski (2001).

Description. - Specimens with 36 to 38 septa of both orders at a diameter of $15 \mathrm{~mm}$ to $29 \mathrm{~mm}$. The septa are very short (up to $3.3 \mathrm{~mm}$ at a diameter of $28 \mathrm{~mm}$, Fig. 11I). The minor septa are $3 / 4$ to $4 / 5$ as long as the length of the major septa. The septa are rudimentary and thickened in continuity with the wall, particularly in juvenile stages (Fig. 11J), when the spaces between the septa are entirerly filled with stereoplasma. The wall varies from 0.7 to $2 \mathrm{~mm}$-thick. The tabulae are subhorizontal or slightly infundibuliform, vesicular and irregularly-space $(2-5 \mathrm{~mm}$ between individual tabula).

Discussion. - The studied specimens fit in the description made by Glinski (2001) for Tryplasma rohrense except that the present specimens are slightly larger (up to $29 \mathrm{~mm}$ in diameter). They differ from fragments of Cyathopaedium paucitabulatum (Schlüter, 1880) occurring in the same beds by the septal development.

Occurrence. - This species is present in Couvin, Baileux and Resteigne, in the lower and middle parts of the Hanonet Fm., below and above the Eifelian-Givetian boundary. This species is known from the Eifelian of the Eifel Mountains (Arhdorf Fm.) (Glinski 2001).

Order Cystiphyllida Nicholson in Nicholson \& Lydekker, 1889

Family Cystiphyllidae Milne-Edwards \& Haime, 1850

\section{Genus Cystiphylloides Chapman, 1893}

Type species. - Cystiphyllum aggregatum Billings, 1859.

Diagnosis. - See McLean (1976).

Cystiphylloides macrocystis (Schlüter, 1889)

Figure 11A-D
*1889 Cystiphyllum macrocystis Schlüter; Schlüter, p. 88, pl. 3, fig. 10.

1995a Mesophyllum (Cystiphylloides) macrocystis macrocystis (Schlüter, 1889). - Schröder, p. 53, pl. 8, fig. 41, textfig. 11. [cum syn.]

1998 Mesophyllum (Cystiphylloides) macrocystis macrocystis (Schlüter, 1889). - Schröder, pp. 75, 76, pl. 21, fig. 123, pl. 23, fig. 128.

1999 Mesophyllum (Cystiphylloides) macrocystis macrocystis (Schlüter, 1889). - Schröder \& Kazmierczak, p. 104, pl. 3, fig. 23.

Material. - Resteigne (RES I-2/1, RES I-3/2 éb., RES I-3/6 éb., RES I-9/2, RES II-5/12, RES II-5/14, RES II-5/14, RES II-5/2 éb., RES II-5/7 éb., RES II-7/1 éb., RES II-9/4), Couvin (COUV I-2/2-3, COUV I-6/10), Nismes (NIS-Ouest/6) and Jemelle (JML-M/5).

Diagnosis. - See McLean (1976).

Description. - Specimens $15 \mathrm{~mm}$ to $41 \mathrm{~mm}$ in diameter. The outer zone comprises medium-sized $(1 \mathrm{~mm}$ on average) dissepiments near the wall and large-sized (1.5 to $2 \mathrm{~mm}$ ) dissepiments/tabellae near the axis of the corallum (Fig. 11E). The dissepiments are globose at the periphery and tend to be elongated near the axis (Fig. 11A). Many corallites display an eccentric axis. There are narrow septal crusts resting on the thickened wall. Thick layers of stereoplasma occur in the middle part of the outer zone. In longitudinal section, the dissepiments are inclined at an angle of 55 to $70^{\circ}$ and forming a sagging layer (Fig. 11B).

Discussion. - The morphological caracteristics of C. macrocystis are well shown in the present specimens. They display the same range of variability as the specimens attributed to that species and figured by Tsien (1969), McLean (1976), Birenheide (1964, 1978), Pedder \& McLean (1982), Soto \& Lin (1995), Schröder (1995a, 1998) and Schröder \& Kazmierczak (1999). This species differs from the other species of Cystiphylloides by the presence of the eccentric axis combined with the well developed septal crust, with the presence of smaller dissepiments at the periphery and larger dissepiments/tabellae near the axis and with

Figure 11. Cystiphyllid tryplasmatid and pycnostillid rugoe corals from the Hanonet Formation. - A-D - Cystiphylloides macrocystis (Schlüter, 1889), specimen RES II-5/7 éb. from Resteigne, TS (A) transverse section, specimen RES II-9/4 from Resteigne, LS (B), specimen RES I-2/1 from Resteigne, TS (C), specimen COUV I-2/2 from Couvin, TS (D). • E, F - Cystiphylloides sp., specimen RES II-5/18 from Resteigne, TS (E), specimen RES I-6/1 éb. from Resteigne, TS (F). • G, H - Microplasma sp., specimen RES I-7/3 from Resteigne, LS (G) and TS (H). $・$ I-K - Tryplasma rohrense Glinski, 2001, specimen BAI-1 from Baileux quarry, TS (I) transverse section, specimen Couvin/17 from Couvin, TS (J) in a juvenile stage, stereoplasma feeling the space between the septa and hiding them and TS (K) in a mature stage, septa going through the stereoplasma. • L-N - Cyathopaedium paucitabulatum (Schlüter, 1880), specimen RES I-6/1 from Resteigne, TS (L), view of the festooned morphology, specimen RES II-5/5 from Resteigne, TS (M), specimen RES I-5/6 from Resteigne, LS (N). Magnification $\times 2$ for A-I and M,N; and $\times 12$ for J,K; and $\times 20$ for $\mathrm{L}$. 

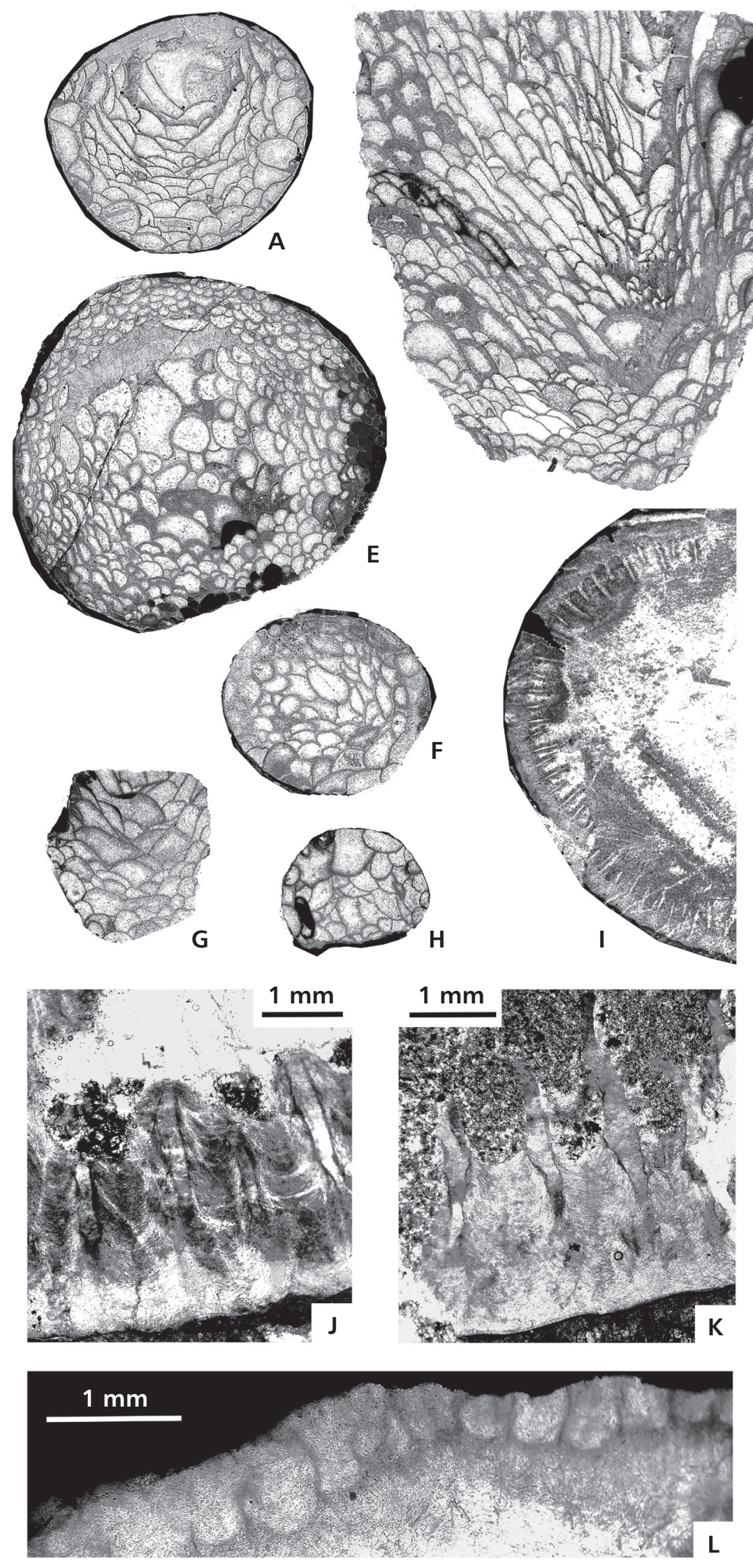
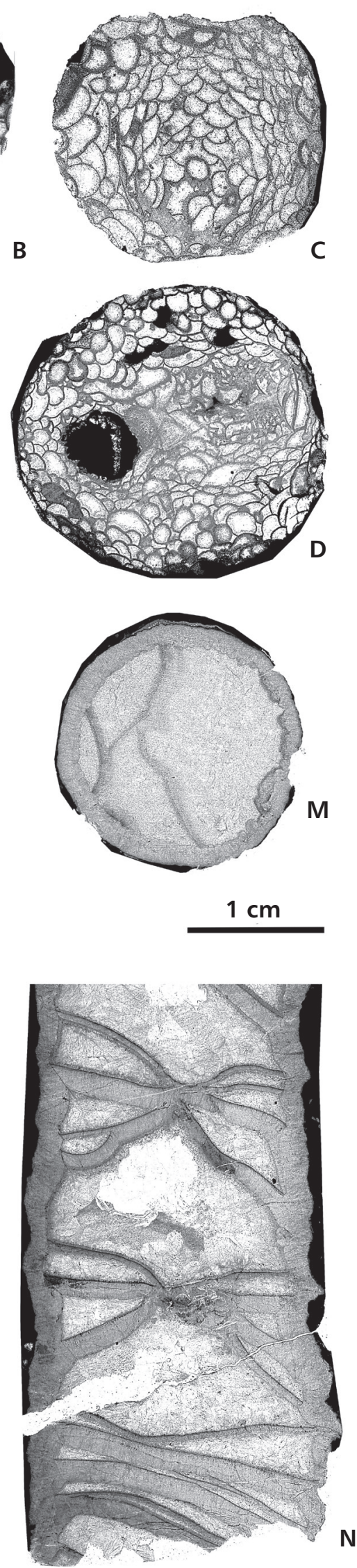
the steeply inclined dissepiments forming a sagging layer.

Occurrence. - The species is a common component of the coral fauna in the Hanonet Fm., in the localities Couvin, Jemelle, Nismes and Resteigne, both in the upper Eifelian ensensis Zone and in the lower Givetian hemiansatus Zone. This species, is also a common component of the Lower-Middle Devonian fauna, known from the Pragian of Tasmania (Pedder \& McLean 1982; Schröder 1995a, 1998), from the Emsian of the Kuznetsk Basin (Bulvanker 1958), from the uppermost Emsian Shanda beds of the Altay Mountains (Pedder \& McLean 1982), from the Eifelian of the Gansu Province (Central China, Soto \& Lin 1995), from the upper Eifelian Hume Fm. of Canada (Mackenzie District) (Pedder \& McLean 1982), from the Eifelian and Givetian of the Eifel Mountains (Jurkerberg to Dreimülhen formations, Birenheide 1964, 1978), Belgium (Tsien 1969), from the lower Givetian of Afghanistan (Pedder \& McLean 1982), eastern Anti-Atlas (Ouihalane “coral reef”) in Morocco (Schröder 1995a, 1998; Schröder \& Kazmierczak 1999), Transcaucasus (Ulitina 1968), Kuznetsk Basin (Padiskyii horizon, Bulvanker 1958) and northern Urals (Soshkina 1936).

Family Digonophyllidae Wedekind, 1923

\section{Genus Mesophyllum Schlüter, 1889}

Type species. - Actinocystis defecta Schlüter, 1882.

Diagnosis. - See Hill (1981).

\section{Mesophyllum vesiculosum (Goldfuss, 1826)}

Figure 12A

*1826 Cyathophyllum vesiculosum nobis; Goldfuss, p. 58, pl. 17, fig. 5e.

1993 Mesophyllum (Mesophyllum) vesiculosum vesiculosum (Goldfuss 1826). - May, pp. 60-62, pl. 10, fig. 4, textfig. 15. [cum syn.]

1998 Mesophyllum (Mesophyllum) vesiculosum vesiculosum (Goldfuss 1826). - Schröder, pp. 68, 69, pl. 18, figs $107,108$.

1998 Mesophyllum (Mesophyllum) sp. cf. vesiculosum vesiculosum (Goldfuss 1826). - Schröder, p. 69, pl. 19, fig. 109.
Material. - Resteigne (RES I-8/1 éb.).

Diagnosis. - See Birenheide (1978).

Description. - Specimens with 41 septa of both orders at a diameter of $35 \mathrm{~mm}$. The septa are discontinuous and reduced to trabeculae in the outer dissepimentarium (Fig. 12A). The major septa reach the centre of the corallum where they form a poorly-defined vortex. The major septa are slightly thicker than the minor septa. The minor septa are $3 / 4$ as long as the length of the major septa. The wall is thickened. The outer dissepimentarium consists of dissepiments of different size and shape. The inner dissepimentarium consists of regular dissepiments. The tabularium is $12.1 \mathrm{~mm}$-wide. In longitudinal section, the dissepiments are inclined at an angle of $15-20^{\circ}$ at the periphery, but as high as $55-60^{\circ}$ near the axis.

Discussion. - The specimen displays the same morphological characters and size as those figured by LeMaître (1947), Birenheide (1964, 1978), May (1993) and Schröder (1998). The species is often referred to be colonial (e.g. Birenheide 1978) but clear offsets have rarely been reported (Birenheide 1964, May 1993, Schröder 1998), suggesting rather a gregarious habit. The present material being fragmented, it was not possible to determinate the habitus.

Occurrence. - The specimen is from Resteigne, from the middle part of the Hanonet Fm., above the EifelianGivetian boundary. This species is known in Germany from the late Eifelian to middle Givetian of the Eifel Mountains (Junkerberg to Kerpen formations) and in the early Givetian of W Sauerland (Birenheide 1964, 1978; May 1993; Schröder 1998). It is known in the Givetian of the French Pyrenees (Joseph \& Tsien 1975) and in the Italian Carnic Alps (Charlesworth 1914). Mesophyllum vesiculosum is also known from the Eifelian and Givetian of North America and the lower Givetian of Morocco (LeMaître, 1947).

\section{General discussions}

On the Belgian shelf, the 'otomari phase' of the Kačák event is seemingly hidden by Struve's Great Gap - corresponding to silicoclastic deposits, as in W Germany (see

Figure 12. Digonophyllid rugose corals from the Hanonet Formation. • A - Mesophyllum vesiculosum (Goldfuss, 1826), specimen RES I-8/1 éb. from Resteigne, TS. • B-G - Mesophyllum sp.1, specimen RES II-5/2 from Resteigne, LS (B), specimen RES I-3/6 éb. from Resteigne, TS (C) in a juvenile and TS (D) in an adult, specimen COUV I-5/3 from Couvin, TS (E), specimen 2004/1d from Resteigne, LS (F), specimen 2004/1a from Resteigne, TS (G). • H-J - Mesophyllum sp. 2, specimen RES II-9/9b from Resteigne, TS (H) in a juvenile stage, specimen 2015.10.13/10a from Couvin, TS (I) in a mature stage, specimen RES II-9/9a from Resteigne, LS (J). Magnification $\times 2$ for specimens A-E and $\times 1$ for specimens F-J. 

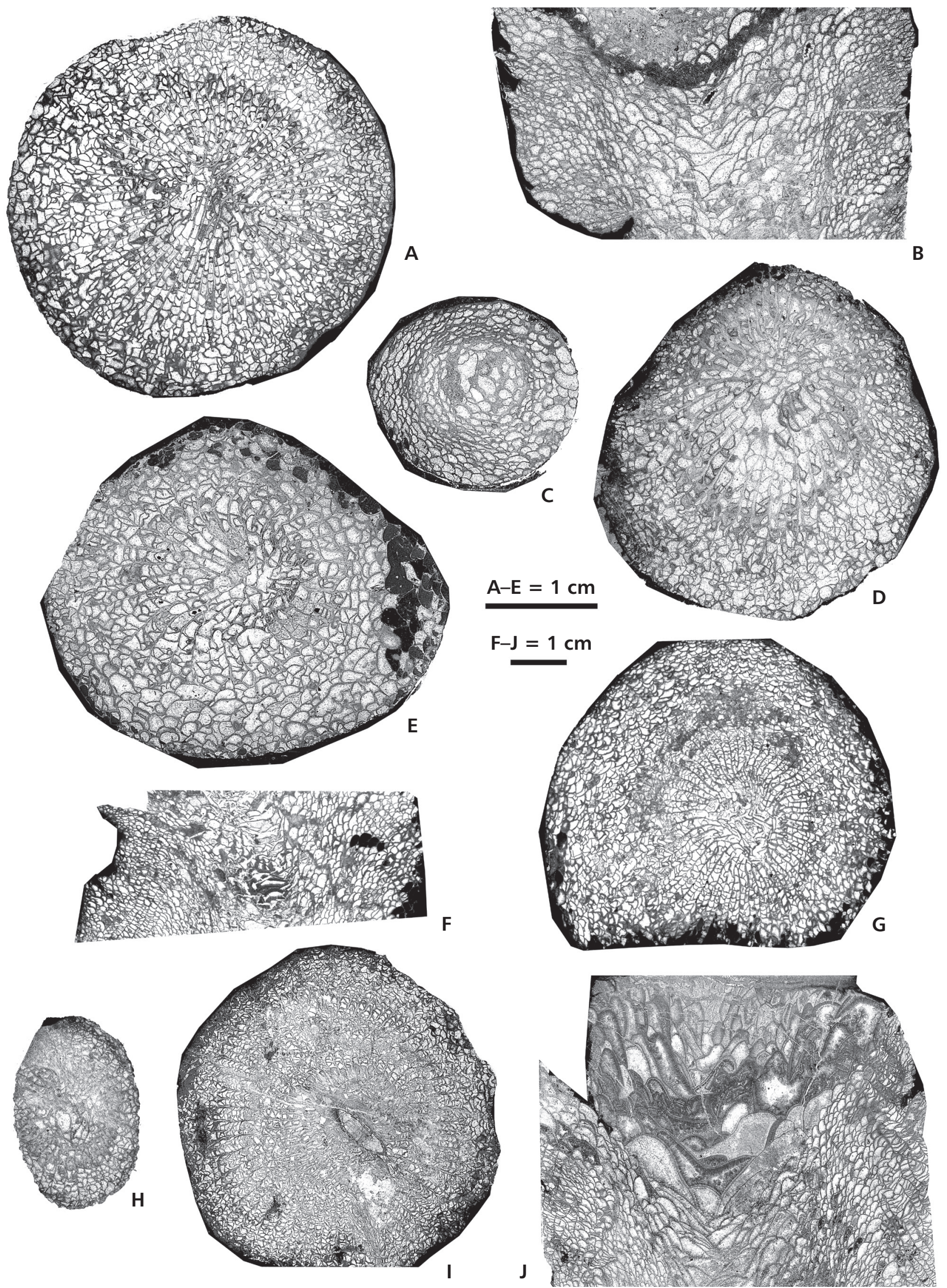
Struve 1982) - which left no trace of a biologic crisis (Bultynck \& Hollevoet 1999). The second phase of the event was driven by a transgressive pulse that led to the deposition of argilo-carbonaceous deposits (Hanonet Fm. in Belgium and Freilingen Fm. in W Germany) (Bultynck \& Hollevoet 1999, Königshof et al. 2016).

The lithological succession observed throughout the Hanonet Fm. is characterized by relatively dark argillaceous fine-grained limestone. As explained above, although they commonly display dark colour, there is no evidence of anoxia. The sediment is usually bioturbated and rather rich in benthic organisms (brachiopods, corals, gastropods, trilobites) and no organism is typicial of oxygen-limited environment (paper-pecten, myodocopid ostracods, Casier et al. 1992). Again, there is no evidence that the Kačák event had a deleterious effect on the benthic fauna on the Belgian shelf.

This absence is the main difference with the German (House 1996, Walliser 1996, Schöne 1997), Czech (Chlupáć \& Kukal 1988, House 1996) and others localities in bathyal settings where the Kačák event shows its most typical features. In shallow-water environments, the typical markers of the Kačák event (dacryoconarids, conodonts and ammonoids) are lacking and the identification of this biocrisis therefore has to be done with others proxies such as trace elements (Königshof et al. 2016) or biotic changes. Such biotic clues are here highlighted.

The lower third of the Hanonet Fm. yielded several coral species belonging to genera typical of the EAR that were unknown before the Hanonet Fm. and limited stratigraphically to this unit. These are Enallophrentis martinae (Coen-Aubert, 1996) and Heliophyllum halleri Schröder, 1995. The Siphonophrentidae genera Breviphrentis, Enallophrentis and Siphonophrentis (see Oliver 1993 for review) most probably originated in the EAR in the Early Devonian and became endemic and diverse in this realm during the Middle Devonian (Schröder 1997b, 2001; Oliver \& Sorauf 2002). Pedder in Pedder \& Feist (1998) has described two older (Emsian) species of Breviphrentis (B. exigua and B. roharti) from the Montagne Noire (France) which has some affinities with the northern margin of Gondwana. Scattered occurrences are known outside EAR: the late Eifelian Enalloprentis martinae (Coen-Aubert, 1996) (= E. rhenana Schröder et al., 1996) in the Freilingen Fm. NE Eifel (Schröder et al. 1996) and Hanonet Fm. of Belgium (Coen-Aubert 1996), the late Eifelian-early Givetian ?Enallophrentis sp. from the Ouihalane reef of Morocco (Schröder \& Kazmierczak 1999) and possibly the late Eifelian Breviphrentis joae Galle, 1995 from Moravia (Galle 1995) but its generic affinity was questioned by Schröder (2001) despite Oliver (1998)'s suggestion of considering it a synonyme of B. simplex Hall, 1843. Occurences in the Givetian in Eifel, Harz, Pyrenees, Devon, Holy Cross Mountains are summarized in Schröder (2001) and Wrzołek (2002). Similarly Heliophyllum is a relatively common genus in the Lower and Middle Devonian strata of the EAR (Oliver \& Sorauf 1988, Oliver 1997) that sporadically appears in the Middle Devonian strata of the OWR, in Western Europe in particular (Schröder 1997b). Schröder (1995a, b) reported Heliophyllum halleri n. sp. in the upper Eifelian Freilingen Fm. and Birenheide (1962) reported Heliophyllum dahlmense (Haller, 1936), Birenheide \& Gabrielli (1993) precise it location in the lower Eifelian Nohn Fm., both in the Eifel Mountains. Additional upper Eifelian occurrences are from Moravia (Galle 1993), Transcaucasus and Urals (Dubatolov \& Spasskiy 1964) and possibly from the Guangxi Province in South China (Oliver \& Sorauf 1988). However, most Heliophyllum species are known from Givetian strata of the OWR (see Oliver \& Sorauf 1988 and references therein). Their peculiar abundance in Spain and Morocco has to be noted (Oliver 1975). The genus Moravophyllum described as closely related to Heliophyllum by Birenheide (1987) and as a subgenus of Heliophyllum by Schröder (1995a, b) is present in the upper Eifelian Freiligen Fm. of the Eifel Mountains. LeMaître (1947) descried in the upper Eifelian-lower Givetian Ouihalane reef of Morocco some corals typical of the EAR including some heliophillids, siphonophrentids and Eridophyllum seriale Milne-Edwars $\&$ Haime, 1850 as the single occurrence of eridophyllid corals known outside North America.

In Spain and Morocco (Oliver 1975, Schröder \& Kazmierczak 1999), the siphonophrentids and heliophyllids seem to be more abundant than in the rest of the OWR, possibly because of geographical proximity with the EAR as suggested by Schröder (2001).

Although limited, the occurrence of siphonophrentids and heliophyllids in the upper Eifelian strata of Western Europe seemingly coincides with the rapid eustatic rise associated with the Kačák event. The higher sea level at this period would have allowed the invasion of the EAR by OWR genera and would also have allowed the escape of EAR genera to the OWR as already suggested by Oliver $(1973,1975,1976)$. So far, this sudden and short-term 'invasion' of EAR fauna on to the Belgian and western German shelves is the most reliable indication of where to place the main phase of the Kačák event.

\section{Conclusions}

Based on faunal changes in pelagic ecosystems, the Kačák event has been identified in many localities around the world (House 1996, 2002; Walliser 1996; DeSantis 2010). The lithological markers of the event typically correspond to the onset of anoxic black shales or dark dysoxic limestone. Typical markers are the joint appearances of the 
dacryoconarid Nowakia otomari, the conodont Polygnathus ensensis, the ammonoids Maenioceras and Agoniatites and the diversification of Cabrieroceras crispiforme, Holzapfeloceras and Wedkindella, together with the disappearance of the dacryoconarid Nowakia chlupaciana and the conodont Tortodus kockelianus (Chlupáć \& Kukal 1988, House 1996, Walliser 1996, Schöne 1997, Chlupáč et al. 2000, DeSantis 2010, Ellwood et al. 2011).

On a global scale, during this 200 ka-long interval (Ellwood et al. 2011, Kido \& Suttner 2011), two of the three faunal realms that were present from the Emsian were dismantled (May 1995, Walliser 1996, DeSantis 2010). The Malvinokaffric Realm disappeared because of global increase of temperatures (May 1995, 1997a, 1997b; Walliser 1996; Boucot et al. 1997; Horodyski et al. 2014). A major transgressive pulse led to the breaching of a continental arch that separated the East Americas Realm from the Old World Realm. Consecutive invasions of fauna from OWR have seemingly driven the EAR fauna to extinction (Oliver 1990, May 1995, DeSantis 2010).

In Belgium, the lack of typical markers of the Kačák event made its identification more complicated. The abrupt arrival of heliophyllid and siphonophrentids rugose corals (extremely rare in Europe before and after the event, Oliver \& Sorauf 1988, Schröder 2001) is likely linked to the late Eifelian transgression that triggered the Kačák event.

This occurrence of EAR corals is used as a potential marker of the Kačák event.

The major facies change occurring at the interface between the Hanonet Fm. (argillaceous fine-grained limestone) and Trois-Fontaines Fm. (massive coarsegrained crinoidal limestone) is probably related to a longterm change of climate change from humid to drier after a short but hot and wet period during the event itself as suggested by Marshall et al. (2007).

\section{Acknowledgements}

We would like to thanks Bernard Mottequin (IRSNB) for the discussions and the help he gave in identifying the brachiopods. Anthony Wright (Wollongong, Australia) and Alan Pedder (Sidney, Canada) for the time they have spent and their advices to increase the quality of this paper. Francis Tourneur and Marie Coen-Aubert are deeply thanked for fruitfull discussion on the Middle Devonian stratigraphy. This research was supported by a CR grant of the Belgian FNRS (project DeCoDE).

\section{References}

Abbasi, M.A., Ashouri, A. \& Khasksar, K. 2014a. Solitary rugose corals from the Givetian of the Khoshyeilagh Formation (Eastern Albroz Mountains, NE Iran). Palaeobiodiversity 7, 1-21.
Abbasi, M.A., Khaksar, K. \& Ashouri, A. 2014b. Some rugose corals from the Devonian (Givetian and Frasnian) of Northeastern Iran. Neues Jahrbuch für Geologie und Paläontologie, Abhandlungen 271(2), 123-139.

DOI 10.1127/0077-7749/2014/0379

BARChY, L. \& MARION, J.-M. 1999. Carte géologique de Wallonie, Chimay-Couvin 57/7-8. 1:25.000. Ministère de la Région wallonne, Direction générale des ressources naturelles et de l'environnement, Namur.

Becker, R.T. \& House, M.R. 1994. International Devonian goniatite zonation, Emsian to Givetian, with new records from Morocco. Courier Forschungsinstitut Senckenberg 169, 79-135.

Becker, T., El Hassani, A. \& TAhiri, A. 2013. International Field Symposium on "The Devonian and Lower Carboniferous of northern Gondwana”. 150 pp. Institut Scientifique, Rabat.

Billings, E. 1859. On the fossil corals of the Devonian rocks of Canada West. Canadian Journal of Industry, Science and Art 4, 97-140.

BirenHeIDE, R. 1962. Die Typen der Sammlung Wedekind aus den Familien Cyathophyllidae und Stringophyllidae (Rugosa). Senckenbergiana lethaea 43(2), 101-123.

BIRENHEIDE, R. 1963. Cyathophyllum-und Dohmophyllum-Arten (Rugosa) aus dem Mitteldevon der Eifel. Senckenbergiana lethaea 44(5), 363-458.

Birenheide, R. 1964. Die "Cystimorpha” aus dem Eifeler Devon. Abhandlungen der senckenbergishen naturforschenden Gesellschaft 507, 1-120.

Birenheide, R. 1972. Ptenophyllidae (Rugosa) aus dem W-deutschen Mitteldevon. Senckenbergiana lethaea 53(5), 405-437.

BIRENHeIDE, R. 1978. Rugose Korallen des Devon. Leitfossilien. 265 pp. Gebrüder Borntraeger, Berlin, Stuttgart.

BiRENHEIDE, R. 1979. Xystriphyllum- und Sociophyllum-Arten (Rugosa) aus dem Eifelium der Eifel. Seckenbergiana lethaea 60(1-3), 189-221.

BIRENHEIDE, R. 1987. Erster Nachweis der rugosen Korallengattug Moravophyllum aus dem Ober-Eifelium der Eifel. Senckenbergiana lethaea 67(5-6), 459-466.

Birenheide, R. \& Gabrielli, P. 1993. Stratigraphie und Korallen des unteren Mittel-Devon im NE-Teil der Rohrer Mulde in der Eifel. Senckenbergiana lethaea 70, 1-28.

Boucot, A.J., Xu, C. \& Scotese, R. 1997. Correlation between geologically marked climatic changes and extinctions. Geobios 20, 61-65. DOI 10.1016/S0016-6995(97)80010-1

Boulvain, F., Coen-Aubert, M., Da Silva, A.C., Kershaw, S., Tourneur, F., Denayer, J., Mottequin, B. \& Poty, E. 2011. Givetian and Frasnian of Southern Belgium. Kölner Forum für Geologie und Paläontologie 20, 5-49.

Budil, P. 1995. Demonstrations of the Kačák event (Middle Devonian, uppermost Eifelian) at some Barrandian localities. Věstník Českého geologického ústavu 70(4), 1-23.

Bultynck, P. 1970. Révision stratigraphique et paléontologique (brachiopodes et conodontes) de la coupe type du Couvinien. Mémoires de l'institut géologique de l'université de Louvain 26, 1-152. 
Bultynck, P. 2006. Couvinian. Geologica Belgica 9(1-2), 147-150.

Bultynck, P. \& Dejonghe, L. 2001. Devonian litostratigraphic units (Belgium). Geologica Belgica 4(1-2), 39-69. DOI $10.20341 / \mathrm{gb} .2014 .043$

Bultynck, P. \& Hollevoet, C. 1999. The Eifelian-Givetian boundary and Struve's Middle Devonian Great Gap in the Couvin area (Ardenne, southern Belgium). Senckenbergiana lethaea 79(1), 3-11. DOI 10.1007/BF03043209

Bultynck, P., Coen-Aubert, M., Dejonghe, L., Godefroid, J., Hance, L., Lacroix, D., Préat, A., Stainier, P., Steemans, P., Streel, M. \& Tourneur, F. 1991. Les formations du Dévonien moyen de la Belgique. Mémoires pour servir à l'explication des cartes géologiques et minières de la Belgique 30, 1-106.

Bulvanker, E.Z. 1958. Devonskie chetyrekhluchevye korally okrain Kuznetskogo basseyna. 212 pp. Vsesoyuznyy Nauchno-Issledovatel'skiy Geologicheskiy Institut (VSEGEI), Leningrad. [in Russian]

Bulvanker, E.Z., Gorianov, V.B., Ivanovski, A.B., Spasskiy, N.YA. \& Shchukina, V.YA. 1968. Novye predstaviteli chetyrekhluchevykh korallovykh polipov SSSR, 14-45. In MArkovskiY, B.P. (ed.) Novye vidy drevnikh rasteniy i bespozvonochnykh SSSR 2(2). Nedra, Moskva. [in Russian]

Casier, J.-G. \& PrÉAt, A. 1990. Sédimentologie et Ostracodes de la limite Eifelien-Givetien à Resteigne (bord sud du Bassin de Dinant, Belgique). Bulletin de l'institut royal des sciences naturelles de Belgique 60, 75-105.

Casier, J.-G., Préat, A. \& Kasimi, R. 1992. Ostracodes et Sédimentologie du sommet de l'Eifelien et de la base du Givetien, à Couvin (bord sud du Bassin de Dinant, Belgique). Bulletin de l'institut royal des sciences naturelles de Belgique 62, 75-108.

Casier, J.-G., Maillet, S., Kasimi, R. \& Préat, A. 2016. Late Eifelian and Early Givetian ostracod assemblages from Wellin, Hotton and On-Jemelle (Ardenne, Dinant Synclinorium, Belgium). Paleoenvironmental implications. Revue de micropaleontologie 58, 287-308.

DOI 10.1016/j.revmic.2015.04.002

Chapman, E.J. 1893. On the corals and coralliform types of Palaeozoic strata. Proceedings and Transactions of the Royal Society of Canada 10(4), 39-48. DOI 10.5962/bhl.title.38717

Charlesworth, J. 1914. Korallen und Stromatoporoiden. Das Devon der Ostalpen, die Fauna des devonischen Riffkalkes IV. Zeitschrift der Deutschen Geologische Gesellschaft 66, 347-407.

Chlupáč, I. \& KuKal, Z. 1986. Reflection of possible global Devonian events in the Barrandian area, C.S.S.R, 169-179. In Walliser, O.H. (ed.) Global Bio-Events. Lecture Notes in Earth Sciences, vol. 8. Springer, Berlin.

DOI 10.1007/BFb0010202

Chlupáč, I. \& Kukal, Z. 1988. Possible global events and the stratigraphy of the Palaeozoic of the Barrandian (CambrianMiddle Devonian), Czechoslovakia. Sbornik geologických věd, Geologie 43, 83-146.

Chlupáč, I., Galle, A., Hladil, J. \& Kalvoda, J. 2000. Series and stage boundaries in the Devonian of the Czech Republic. Courier Forschungsinstitut Senckenberg 225, 159-172.
Coen-Aubert, M. 1988. Représentant des genres Sociophyllum Birenheide, 1962 et Beugniesastrea n. gen. à la base du Calcaire de Givet de Pondrôme et Resteigne (bord sud du Bassin de Dinant, Belgique). Bulletin de l'institut royal des Sciences naturelles de Belgique 58, 5-31.

Coen-Aubert, M. 1989. Description de quelques Rugueux coloniaux du Couvinien supérieur de Wellin (bord sud du Bassin de Dinant, Belgique). Bulletin de l'institut royal des Sciences naturelles de Belgique 59, 15-35.

Coen-Aubert, M. 1990. Deuxième note sur les Rugueux coloniaux de l'Eifelien supérieur et de la base du Givetien à Wellin (bord sud du Bassin de Dinant, Belgique). Bulletin de l'institut royal des Sciences naturelles de Belgique 60, 5-28.

Coen-Aubert, M. 1992. Rugueux coloniaux mésodévoniens du Fondry des Chiens à Nismes (Ardenne, Belgique). Bulletin de l'institut royal des Sciences naturelles de Belgique 62, $5-21$.

Coen-Aubert, M. 1996. Siphonophrentides et Cyathophyllides près de la limite Eifelien-Givetien à Resteigne (Ardenne, Belgique). Bulletin de l'institut royal des Sciences naturelles de Belgique 66, 19-36.

Coen-Aubert, M. 1997. Rugueux solitaires près de la limite Eifelien-Givetien à Pondrôme (Belgique). Bulletin de l'institut royal des Sciences naturelles de Belgique 67, 5-24.

Coen-Aubert, M. 1998. Thamnophyllides et Acanthophyllides près de la limite Eifelien-Givetien à Wellin et Pondrôme (Belgique). Bulletin de l'institut royal des Sciences naturelles de Belgique 68, 5-24.

Coen-Aubert, M. 2000. Stratigraphy and additional rugose corals from the Givetian Mont d'Haurs Formation in the Ardennes. Bulletin de l'institut royal des Sciences naturelles de Belgique 70, 5-23.

Coen-Aubert, M. 2008. Fasciculate Dysphyllids (Rugosa) from the Early Givetian Trois-Fontaines Formation in Belgium. Bulletin de l'institut royal des Sciences naturelles de Belgique 78, 31-50.

Coen-Aubert, M. 2011. Reassignment to the Middle Devonian of some rugose corals investigated by LeMaître (1934) in the Chalonnes Formation from the Southeastern Armorican Massif (France). Bulletin de l'institut royal des Sciences naturelles de Belgique 81, 27-53.

Coen-Aubert, M. \& Lütte, B.-P. 1990. Massive rugose corals from the Middle Devonian of the North Eifel Hills (Rheinisches Schiefergebirge, West Germany). Geologica et Palaeontologica 24, 17-39.

Coen-Aubert, M. \& Wrzolek, T. 1991. Redescription of the rugose coral Macgeea (Rozkowskaella) sandaliformis (Rożkowska, 1980) from the Upper Frasnian of the Holy Cross Mountains (Poland). Bulletin de l'institut royal des Sciences naturelles de Belgique 61, 5-19.

Coen-Aubert, M., Mamet, B., Préat, A. \& Tourneur, F. 1991. Sédimentologie, paléoécologie et paléontologie des calcaires crinoïdiques au voisinage de la limite Couvinien - Givetien à Wellin (bord sud du Synclinorium de Dinant, Belgique). Mémoires pour servir à l'Explication des Cartes Géologiques et Minières de la Belgique 31, 1-61.

Crônier, C. \& VAN VIERsEn, A. 2007. Trilobite palaeobiodiversity 
during the Devonian in the Ardennes Massif. Bulletin de la Société Géologique de France 178(6), 473-483. DOI 10.2113/gssgfbull.178.6.473

DANA, J.D. 1846a. Genera of fossil corals of the family Cyathophyllidae. The American Journal of Science and Arts 1(2), 178-189.

DANA, J.D. 1846b. Zoophytes. United States Exploring Expedition during the years 1838-1842, under the command of Charles Wilkes, U.S.N. Vol. 7. 740 pp. Lea and Blanchard, Philadelphia.

Denayer, J. 2019. Revised stratigraphy of the Eifelian (Middle Devonian) of southern Belgium: sequence stratigraphy, global events, reef development and basin structuration. Geologica Belgica 22(3-4), 149-173. DOI 10.20341/gb.2019.009

DeSantis, M.K. 2010. Anatomy of Middle Devonian Faunal Turnover in Eastern North America: Implications for Global Bioevents at the Eifelian-Givetian Stage Boundary. 409 pp. $\mathrm{Ph} . \mathrm{D}$. thesis, University of Cincinnati, U.S.A.

DeSantis, M.K. \& Brett, C.E. 2011. Late Eifelian (Middle Devonian) biocrises: timing and signature of the pre-Kačák Bakoven and Stony Hollow events in eastern North America. Palaeogeography, Palaeoclimatology, Palaeoecology 304(1-2), 113-135. DOI 10.1016/j.palaeo.2010.10.013

Dubatolov, V.N. \& SpasskiY, N.YA. 1964. Stratigraficheskiy i geograficheskiy obzor devonskikh korallov SSSR. 152 pp. Nauka, Moscow. [in Russian]

EhrenberG, C.G. 1834. Beiträge zur physiologischen Kenntniss der Corallenthiere im allgemeinen, und besonders des Rothen Meeres, nebst einem Versuche zur physiologischen Systematik derselben. Abhandlungen der Preussichen Akademie der Wissenschaften, Physikalisch-Mathematisch Klasse, 1832, 225-380.

Ellwood, B.B., Algeo, T.J., El Hassani, A., Tomkin, J.H. \& Rowe, H.D. 2011. Defining the timing and duration of the Kačák Interval within the Eifelian/Givetian boundary GSSP, Mech Irdane, Morocco, using geochemical and magnetic susceptibility patterns. Palaeogeography, Palaeoclimatology, Palaeoecology 304(1-2), 74-84.

DOI 10.1016/j.palaeo.2010.10.012

Etheridge, R. 1907. A Monograph of the Silurian and Devonian corals of New South Wales. Part II. The genus Tryplasma. Memoirs of the Geological Survey of New South Wales, Palaeontology 13, 41-102.

FreCH, F. 1885. Ueber das Kalkgerüst der Tetrakorallen. Zeitschrift der Deutschen Geologischen Gesellschaft 37, 928-945.

Frech, F. 1886. Die Cyathophylliden und Zaphrentiden des deutsche Mitteldevon, eingeleitet durch den Versuch einer Gliederung desselben. Palaeontologische Abhandlugen 3(3), $1-120$.

Galle, A. 1993. Middle Devonian Rugosa from Horní Benešov (Moravia, Czech Republic). Journal of the Czech Geological Society 38(1-2), 59-70.

Galle, A. 1995. The Breviphrentis-dominated coral faunule from the Middle Devonian of Moravia, Czech Republic. Věstník Českého geologického ústavu 70(2), 59-70.

García-Alcalde, J.L. \& Soto, F. 1999. El límite Eifeliense/ Givetiense (Devónico Medio) en la Cordillera Cantábrica
(N de España). Revista Española de Paleontología, $n^{\circ}$ extra Homenaje al Prof. J. Truyols, 43-56.

García-López, S., Sanz-López, J. \& Sarmiento, G.N. 2002. The Palaeozoic succession and conodont biostratigraphy of the section between Cape Peñas and Cape Torres (Cantabrian coast, NW Spain), 125-161. In GARCíA-LóPEZ, S. \& BASTIDA, F. (eds) Palaeozoic conodonts from northern Spain. Eight International Conodont Symposium held in Europe. Madrid, Publicaciones del Instituto Geológico y Minero de España.

Glinski, A. 1955. Cerioide Columnariidae (Tetracoralla) aus dem Eifelium der Eifel und des Bergischen Landes. Seckenbergiana lethaea 36, 73-114.

Glinski, A. 2001. Tryplasma (Anthozoa, Rugosa) im MittelDevon der Eifel (Rheinisches Schiefergebirges, Deutschland). Senckenbergiana lethaea 81(1), 71-89. DOI 10.1007/BF03043295

Goderroid, J. 1968. Contribution à l'étude du Couvinien entre Wellin et Jemelle (Bord sud du basin de Dinant). Mémoires de l'Académie Royale de Belgique, Classe des Sciences, 2e série 17(3), 1-87.

Goderroid, J. 1995. Les brachiopodes (Pentamerida, Atrypida et Spiriferida) de la fin de l'Eifelien et du début du Givetien à Pondrôme (Belgique, bord sud du Synclinorium de Dinant). Bulletin de l'institut royal des Sciences naturelles de Belgique 65, 69-116.

Goldfuss, A. 1826. Petrefacta Germaniae. 76 pp. Arnz \& Comp., Düsseldorf.

Gouwy, S. \& Bultynck, P. 2003. Conodont based graphic correlation of the Middle Devonian formations of the Ardenne (Belgium): implications for stratigraphy and construction of a regional composite. Revista española de Micropaleontologia 35(3), 315-344.

GÜRICH, G. 1896. Das Paläozoicum im Polischen Mittelgebirge. Verhandlungen der Russich-Kaiserlichen Mineralogischen Gesellschaft 32, 1-539.

Hall, J. 1843. Geology of New York, Part 4, comprising the survey of the fourth geological district. Natural History of New York. 683 pp. Carroll \& Cook Ed., Albany, New York.

Hall, J. \& Whitfield, R.P. 1873. Descriptions of new species of fossils from the Devonian rocks of Iowa. Annual Report of the Regents of the University of the State of New York on the Condition of the State Cabinet of Natural History 23, 223-239.

Haller, W. 1936. Einige biostratigraphische Unterschungen in der Roher Mulde unter besonderer Berücksichtigung der Keriophyllen. Jahrbuch der Preussischen Geologischen Landesanstalt zu Berlin 56, 590-632.

HiLl, D. 1942. The Middle Devonian rugose corals of Queensland, III. Burdekin Downs, Fanning River and Ried Gap, north Queensland. Proceedings, Royal Society of Queensland 53, 229-268.

Hill, D. 1981. Rugosa and Tabulata, 1-378. In Teichert, C. (ed.) Treatise on Invertebrate Paleontology, part F, supplement 1-2. Geological Society of America \& The University of Kansas Press, Boulder, Colorado and Lawrence, Kansas.

Hladil, J. \& Kalvoda, J. 1993, Extinction and recovery successions of the Devonian marine shoals: Eifelian-Givetian 
and Frasnian-Famennian events, Moravia and Bohemia. Věstník Českého geologického ústavu 68(4), 13-23.

Horodyski, R.S., Holz, M., Grahn, Y. \& Bosetti, E. 2014. Remarks on sequence stratigraphy and taphonomy of the Malvinokaffric shelly fauna during the Kačák Event in the Apucarana Sub-basin (Paraná Basin), Brazil. International Journal of Earth Sciences 103(1), 367-380.

DOI 10.1007/s00531-013-0954-9

House, M.R. 1985. Correlation of mid-Palaeozoic ammonoid evolutionary events with global sedimentary perturbations. Nature 313(5997), 17-22. DOI 10.1038/313017a0

House, M.R. 1996. The middle Devonian Kačák event. Proceedings of the Ussher Society 9, 79-84.

House, M.R. 2002. Strength, timing, setting and cause of midPalaeozoic extinctions. Palaeogeography, Palaeoclimatology, Palaeoecology 181(1-3), 5-25.

DOI 10.1016/S0031-0182(01)00471-0

Joseph, J. \& Tsien, H.H. 1975. Calcaires mésodévoniens et leur faune de tétracoralliaires en haute Vallée d'Ossau (PyrénéesAtlantiques). Bulletin de la Société d'Histoire naturelle de Toulouse 111(1-2), 179-203.

KAsimi, R. \& PrÉAt, A. 1996. Sédimentation de rampe mixte silico-carbonatée des couches de transition eiféliennesgivétiennes franco-belges. Deuxième partie: cyclostratigraphie et paléostructuration. Bulletin des Centres de recherches exploration-production Elf-Aquitaine 20(1), 61-90.

Kettnerová, M. 1932. Palaeontological Studies of the Devonian of Čelechovice (Moravia). Part IV. Rugosa. Práce geologickopalaeontologického ústavu Karlovy university v Praze za rok 1932, 1-97.

Kido, E. \& SutTneR, T.J. 2011. A new project has been launched: FWF P23775-B17 "Late Eifelian climate perturbations: Effects on tropical coral communities". Jahrbuch der Geologischen Bundesanstalt 151(3-4), 407-416.

Königshof, P., Da Silva, A.C., Suttner, T.J., Kido, E., Waters, J., Carmichael, S.K., Jansen, U., Pas, D. \& Spassov, S. 2016. Shallow-water facies setting around the Kačák Event: a multidisciplinary approach, 171-199. In BECKER, R.T., Königshof, P. \& Brett, C.E. (eds) Devonian Climate, Sea Level and Evolutionary Events. Geological Society London, Special Publication 423. DOI 10.1144/SP423.4

Königshof, P., Narkiewicz, K., Hoa, P.T., Carmichael, S.K. \& Waters, J.A. 2017. Devonian events: examples from the eastern Palaeotethys (Si Phai section, NE Vietnam). Palaeobiodiversity and Palaeoenvironments 97(3), 481-496. DOI 10.1007/s12549-017-0272-5

LeMaître, D. 1947. Contribution à l'étude du Dévonien $\mathrm{du}$ Tafilalet. II. Le récif coralligène de Ouihlane. Notes et Mémoires du Service des Mines et de la Carte Géologique du Maroc 67, 1-112.

LinNAEus, C. 1771. Mantissa plantarum altera generum editionis VI \& specierum editionis II. 143-588 pp. Laurentii Salvii, Stockholm.

Lonsdale, W. 1845. Description of some characteristic Palaeozoic corals of Russia, 591-634. In Murchinson, R.I., De Verneuil, E. \& von Keyserling, A. (eds) Géologie de la Russie d'Europe et des montagnes de l'Oural v. 1. John Murray, London.
LÜtTE, B.-P. 1987. Glossophyllum-Arten aus dem MittelDevon der Eifel (Rugosa; Rheinisches Schiefergebirge). Senckenbergiana lethaea 67(5-6), 433-457.

Mabille, C. \& Boulvain, F. 2008. Les Monts de Baileux section: Detailed sedimentology and magnetic susceptibility of Hanonet, Trois-Fontaines and Terres d'Haurs Formations (Eifelian/Givetian boundary and lower Givetian, SW Belgium). Geologica Belgica 11, 93-121.

Mamet, B. \& Préat, A. 2005. Microfacies d'une lentille biohermale à la limite Eifelien/Givetien (Wellin, bord Sud du Synclinorium de Dinant). Geologica Belgica 8(3), 85-111.

Marshall, J.E.A. 2016. Palynological calibration of Devonian events at near-polar paleolatitudes in the Falkland Islands, South Atlantic, 25-44. In BeCKer, R.T., KöNIGShof, P. \& BretT, C.E. (eds) Devonian Climate, Sea Level and Evolutionary Events. Geological Society London, Special Publication 423. DOI 10.1144/SP423.13

Marshall, J.E.A., Astin, T.R., Brown, J.F., Mark-Kurik, E. \& Lazauskiene, J. 2007. Recognizing the Kačák Event in the Devonian terrestrial environment and its implications for understanding land-sea interactions, 133-155. In BECKER, R.T. \& Kirchgasser, W.T. (eds) Devonian Events and Correlations. Geological Society London, Special Publication 278. DOI 10.1144/SP278.6

Maurer, F. 1885. Die Fauna der Kalke von Waldgrimes bei Giessen. Abhandlungen der Hessishen geologischen LandesAnstalt 1(2), 63-340.

MAY, A. 1993. Korallen aus dem höheren Eifelium und unteren Givetium (Devon) des Nordwestlichen Sauerlandes (Rheinisches Schiefergebirge) Teil II: Rugose Korallen, Chaetetiden und Spezielle Themen. Paleontographica 228, $1-103$.

MAY, A. 1995. Relationship among sea-level fluctuation, biogeography, and bioevents of the Devonian: an attempt to approach a powerful, but simple model for complex longrange control of biotic crises. Geolines 3, 38-49.

MAY, A. 1997a. Ein Modell zur Erklärung der Bio-Events und der biogeographischen Entwicklung im Devon durch den Meeresspiegel. Dortmunder Beiträge zur Landeskunde 31, 137-174.

MAY, A. 1997b. Gedanken über Zusammenhänge zwischen Meeresspiegel, Biogeographie und Bio-Events im Devon. Coral Research Bulletin 5, 291-318.

Merriam, C.W. 1974a. Lower and lower Middle Devonian rugose corals of the central Great Basin. U.S. geological Survey professional Paper 805, 1-83. DOI 10.3133/pp805

Merriam, C.W. 1974b. Silurian Rugose Corals of the Central and Southwest Great Basin. U.S. Geological Survey Professional Paper 777, 1-99. DOI 10.3133/pp777

Milne-Edwards, H. \& Haime, J. 1850. A Monograph of the British Fossil Corals. Part 1, Introduction, corals from the Tertiary and Cretaceous formations. $71 \mathrm{pp}$. The Palaeontographical Society, London. DOI 10.1017/CBO9781316143445.003

Milne-Edwards, H. \& Haime, J. 1851. Monographie des Polypiers fossiles des terrains paléozoïques. Archives $d u$ Muséum d'Histoire Naturelles 5, 1-502.

McLean, R.A. 1976. Middle Devonian Cystiphyllid corals from 
the Hume Formation, Northwestern Canada. Geological survey of Canada 274, 1-80. DOI 10.4095/103067

Nicholson, H.A. \& Lydekker, R. 1889. A Manual of Palaeontology, for the Use of Students: With a General Introduction of the Principles of Palaentology, vol. 1, $3^{\text {rd }}$ edition. $885 \mathrm{pp}$. Wm. Blackwood and Sons, Edinburgh and London. DOI 10.5962/bhl.title.61545

Oliver, W.A., JR. 1973. Devonian coral endemism in Eastern America and its bearing on palaeogeography. Special Papers in Paleontology 12, 318-319.

OLIVER, W.A., JR. 1975. Endemism and evolution of Late Silurian to Middle Devonian rugose corals in Eastern North America. Academy of Sciences of the U.S.S.R., Siberian Filial, Transactions of the Institute of Geology and Geophysics 202 (Ancient Cnidaria, v. 2), 148-160.

OLIVER, W.A., JR. 1976. Noncystimorph colonial rugose corals of the Onesquethaw and lower Cazenovia Stages (Lower and Middle Devonian) in New York and adjacent areas. United States Geological Survey Professional Paper 869, 1-156. DOI 10.3133/pp869

Oliver, W.A., JR. 1990. Extinctions and migrations of Devonian rugose corals in the Eastern Americas Realm. Lethaia 23, 167-178. DOI 10.1111/j.1502-3931.1990.tb01358.x

OlIVER, W.A., JR. 1993. The Siphonophrentidae (Rugose Corals, Devonian) of Eastern North America. United State Geological Survey, Bulletin 2024-B, 1-32.

Oliver, W.A., JR. 1997. Origins and relationships of colonial Heliophyllum in the upper Middle Devonian (Givetian) of New York. Boletín de la Real Sociedad Espñola de Historia Natural (Seccion Geologica) 91(1-4), 53-60.

OLIVER, W.A., JR. 1998. Nomenclatural problems of Breviphrentis Stumm, 1949 and Contophrentis new genus (Devonian rugose corals). Journal of Palaeontology 72(5), 932-934. DOI 10.1017/S0022336000027256

Oliver, W.A., JR. \& Pedder, A.E.H. 1979a. Biogeography of Late Silurian and Devonian Rugose Corals in North America. Historical Biogeography, Plate Tectonics, and the Changing Environment. Oregon State University Press, Corvallis, 131-145.

Oliver, W.A., JR. \& Pedder, A.E.H. 1979b. Rugose corals in Devonian stratigraphical correlation. Special Papers in Palaeontology 23, 233-248.

Oliver, W.A., Jr. \& Pedder, A.E.H. 1994. Crises in the Devonian history of the rugose corals. Paleobiology 20(2), 178-190. DOI 10.1017/S0094837300012665

Oliver, W.A., JR. \& Sorauf, J.E. 1988. Heliophyllum hall and Charisphyllum n. gen. (Devonian rugose corals) of the Cantabrian Mountains (NW Spain). Trabajos de Geologia, Universidad de Oviedo 17, 3-17.

Oliver, W.A., JR. \& Sorauf, J.E. 2002. The Genus Heliophyllum (Anthozoa, Rugosa) in the Upper Middle Devonian (Givetian) of New York. Bulletins of American Paleontology 362, $1-72$.

Pedder, A.E.H. 1976. First records of five rugose coral genera from Upper Silurian rocks of the Canadian Arctic Islands. Geological Survey of Canada, Paper 76-1B, 287-293. DOI 10.4095/104114
Pedder, A.E.H. 1982. Chostophyllum, a new genus of charactophyllid corals from the Middle Devonian of western Canada. Journal of Paleontology 56(3), 559-582.

Pedder, A.E.H. 2002. New systematic and biostratigraphic data concerning the Breviphyllidae (Lower Devonian Rugosa) of Nevada. Coral Research Bulletin 7, 141-166.

Pedder, A.E.H. \& Feist, R. 1998. Lower Devonian (Emsian) Rugosa of the Izarne formation, Montagne Noire, France. Journal of Paleontology 72(6), 967-991.

DOI $10.1017 / \mathrm{S} 0022336000027347$

Pedder, A.E.H. \& McLean, R. 1982. Lower Devonian cystiphyllid corals from North America and eastern Australia with notes on the genus Utaratuia. Geologica et Palaeontologica 16, $57-110$.

Pedder, A.E.H., Norford, B.S., \& Irish, E.J.W. 1971. Dohmophyllum and a new related genus of corals from the Middle Devonian of northwestern Canada. Contributions to Canadian Paleontology. Geological Survey of Canada, Bulletin 197, 37-77. DOI 10.4095/102339

PréAt, A. 1989. Sedimentology, facies and depositional environment of the Hanonet (upper Eifelian) and TroisFontaines (lower Givetian) formations in Couvin area (Dinant basin, Belgium). Bulletin de la Société belge de Géologie 98(2), 149-154.

Préat, A. \& Kasimi, R. 1995. Sédimentation de rampe mixte silico-carbonatée des couches de transition eiféliennesgivétiennes franco-belges. Première partie: Microfaciès et modèle sédimentaire. Bulletin des Centres de recherches exploration-production Elf-Aquitaine 19(2), 329-375.

Préat, A., Coen-Aubert, M., Mamet, B. \& Tourneur, F. 1984. Sédimentologie et paléoécologie de trois niveaux récifaux du Givetien inférieur de Resteigne (bord Sud du bassin de Dinant, Belgique). Bulletin de la Société belge de Géologie 93(1-2), 227-240.

Qie, W., Ma, X., Xu, H., Qiao, L., Liang, K., Guo, W., Song, J., Chen, B. \& Lu, J. 2018. Devonian integrative stratigraphy and timescale of China. Science China Earth Sciences 61, 1-23. DOI 10.1007/s11430-017-9259-9

RoEMER, C.F. 1883. Lethaea geognostica oder Beschreibung und Abbildung der fûr die Gebirgs-Formationen bezeichnendsten Versteinerungen. I. Theil, Lethaea palaeozoica. 324-543 pp. Zweite Lieferung, Stuttgart.

SCHLÜTER, C. 1880. Über Zoantharia rugosa aus dem rheinischen Mittel- und Ober-Devon. Sitzungs-bericht der Gesellschaft naturforschender Freunde zu Berlin 1880(3), 50-53. DOI 10.5962/bhl.part.14941

SCHLÜTER, C. 1881. Über einige Anthozoen des Devon. Zeitschrift der Deutschen Geologischen Gesellschaft 33(1), 75-108.

SCHLÜTER, C. 1882. Über neue Korallen des Mitteldevon der Eifel. Sitzungsberichte der niederrheinischen Gesellschafte fur Natur- und Heilkunde in Bonn. Verhandlungen des naturhistorischen Vereines der preussischen Rheinlande und Westfalens 39, 205-210.

SCHLÜter, C. 1889. Anthozoen des rheinischen Mittel-Devon. Abhandlungen zur geologischen Specialkarte von Preussen und der Thüringischen Staaten 8(4), 1-207.

SCHÖNE, B.R. 1997. Der otomari-Event und seine Auswirkungen 
auf die Fazies des Rhenoherzynishen Schelfs (Devon, Rheinisches Schiefergebirge). Göttinger Arbeiten zur Geologie und Paläontologie 70, 1-147.

DOI 10.1016/j.tecto.2013.02.037

SchröDER, S. 1995a. Rugose Korallen aus der FreilingenFormation der Dollendorfer Mulde (Ober-Eifelium/ Mitteldevon; Eifel/Rheinisches Schiefergebirge). Senckenbergiana lethaea 75(1-2), 33-75.

SCHröDER, S. 1995b. Die Korallenfauna des Kirchen-Berges (Freilingen-Formation) in der Blankenheimer Mulde (Rheinisches Schiefergebirge/Eifel). Münstersche Forschungen zur Geologie und Paläontologie 77, 373-421.

SCHRÖDER, S. 1996. Revision der rugosen Koralle Macgeea bathycalyx (FRECH 1886) (Mitteldevon, Rheinisches Schiefergebirge). Senckenbergiana lethaea 76(1-2), 53-63. DOI 10.1007/BF03042841

SCHRÖDER, S. 1997a. Die Rugosen-Fauna des Eilenbergium der Dollendorfer Mulde (Mittel-Devon/Ober-Eifelium; Rheinisches Schiefergebirge/Eifel). Geologica et Palaeontologica 31, 1-36.

Schröder, S. 1997b. Upper Eifelian (Middle Devonian) rugose corals of the Eifel Hills (Germany) and their relation to North American and Eastern European taxa. Boletín de la Real Sociedad Española de Historia Natural 92(1-4), 271-279.

SCHRÖDER, S. 1997c. Rugose Korallen aus dem "Bouderath-Riff" (Eifelium/Ahrdorf-Formation) der Blankenheimer Mulde/ Eifel. Coral Research Bulletin 5, 211-220.

Schröder, S. 1998. Rugose Korallen und Stratigraphie des oberen Eifelium und unteren Givetium der Dollendorfer Mulde/Eifel (Mittel-Devon; Rheinisches Schiefergebirge). Courier Forschungsinstitut Senckenberg 208, 1-140.

SCHRÖDER, S.2001. On some westernEuropean Siphonophrentidae. Bulletin of the Tohoku University Museum 1, 254-264.

SCHRÖDER, S. 2002. Rugose Korallen aus dem hohen Givetium und tiefen Frasnium (Devon) des Messinghäuser Sattels (Rheinisches Schiefergebirge/Sauerland). Coral Research Bulletin 7, 175-189.

SChröder, S. 2005. Stratigraphie und Systematik rugoser Korallen aus dem Givetium und Unter-Frasnium des Rheinischen Schiefergebirges (Sauerland/Bergisches Land). Zitteliana B25, 39-116.

SCHRÖDER, S. 2007. Colonial Rugosa from the Early Devonian (Pragian) of the Zeravshan Range, Tajikistan. Alcheringa 31, 121-151. DOI 10.1080/03115510701305124

Schröder, S. \& KazmierczaK, M. 1999. The Middle Devonian "coral reef" of Ouihlane (Morocco) - New data on the geology and rugose coral fauna. Geologica et Palaeontologica 33, 93-115.

Schröder, S., LÜtte, B.-P. \& OeKentorp, K. 1996. Enallophrentis (Rugosa, Siphonophrentidae) aus dem Ober-Eifelium/MittelDevon der Dollendorfer Mulde (Rheinisches Schiefergebirge/ Eifel). Geologica et Palaeontologica 30, 15-31.

Schulz, E. 1883. Die Eifelkalkmulde von Hillesheim. Jahrbuch peruse geologische Landesandalt 3, 158-250.

Scotese, C.R. 2014. Atlas of Devonian Paleogeographic Maps, PALEOMAP Atlas for ArcGIS, volume 4, The Late Paleozoic,
Maps 65-72. Mollweide Projection, PALEOMAP Project, Evanston, IL.

SHrock, R.R. \& Twenhofel, W.H. 1953. Principles of invertebrate palaeontology. 816 pp. McGraw-Hill, New York.

Shurigina, M.V. 1972. Podklass Tetracoralla, 98-113. In KhodaleVITCH, A.N. (ed.) Kishechnopolostnye i brakhiopody zhivetskikh otlozheniy vostochnogo sklona Urala. Izdatelstvo Nedra, Moskva. [in Russian]

Smith, S. \& Thomas, H.D. 1963. On Amplexus coralloides Sowerby and some ampleximorph corals from the English Devonian. The Annals and Magazine of Natural History 13(6), 161-172. DOI 10.1080/00222936308651337

SoshkinA, E.D. 1936. Korally Rugosa srednego devona Severnogo Urala. Akademiya Nauk SSSR, Trudy Polyarnoy Komissii 28, 15-76. [in Russian]

Soto, F. \& Lin, B. 1995. Corales rugosos Cistimorfos del Devónico del Suroeste de las Montañas de Qingling (Provencia de Gansu, China). Geobios 28(3), 293-315. DOI 10.1016/S0016-6995(95)80005-0

Stampfli, G.M., von Raumer, J. \& Borel, G.D. 2002. Paleozoic evolution of pre-Variscan terranes: From Gondwana to the Variscan collision, 263-280. In Martínez Cotalán, J.R., Hatcher, R.D., Jr., Arenas, R. \& Díaz García, F. (eds) Variscan-Appalachian dynamics: The building of the late Paleozoic basement. Geological Society of America, Special Paper 364. Boulder, Colorado.

DOI 10.1130/0-8137-2364-7.263

Stampfli, G.M., Hochard, C., Vérard, C., Wilhem, C. \& von Raumer, J. 2013. The formation of Pangea. Tectonophysics 593, 1-19. DOI 10.1016/j.tecto.2013.02.037

Struve, W. 1982. The Great Gap in the record of marine Middle Devonian. Courier Forschungsinstitut Senckenberg 55, 433-448.

Talent, J.A., Mawson, R., Andrew, A.S., Hamilton, P.J. \& Whitford, D.J. 1993. Middle Palaeozoic extinction events: Faunal and isotopic data. Palaeogeography, Palaeoclimatology, Palaeoecology 104(1-4), 139-152. DOI 10.1016/0031-0182(93)90126-4

Troth, I., Marshall, J.E.A., Racey, A. \& Becker, R.T. 2011. Devonian sea-level change in Bolivia: A high palaeolatitude biostratigraphical calibration of the global sea-level curve. Palaeogeography, Palaeoclimatology, Palaeoecology 304(1-2), 3-20. DOI 10.1016/j.palaeo.2010.10.008

Truyóls-Massoni, M., Montesinos, R., Garcia-Alcalde, J. \& Leyva, F. 1990. The Kačák-otomari event and its characterization in the Palentine domain (Cantabrian Zone, NW Spain), 133-143. In Kauffman, E.G. \& Walliser, O.H. (eds) Extinction Events in Earth History. Springer-Verlag, Berlin, Heidelberg. DOI 10.1007/BFb0011141

Tsien, H.-H. 1969. Contribution à l'étude des Rugosa du Couvinien dans la région de Couvin. Mémoires de l'institut géologique de l'université de Louvain 25, 1-174.

Tsyganko, V.S. 1977. Novye jivetskie vidy rugoz PayKhoya, 31-32. In Stukalina, G.A. (ed.) Novye vidy drevnikh rasteniy i bespozvonochnykh SSSR 4. Nauka, Moskva. [in Russian]

Ulitina, L.M. 1968. Devonskie korally tsistifilliny Zakavkaz’ya. 
Akademiya Nauk SSSR, Trudy Paleontologicheskogo Instituta 113, 1-119. [in Russian]

van Hengstum, P.J. \& Gröcke, D.R. 2008. Stable isotope record of the Eifelian-Givetian boundary Kačák-otomari Event (Middle Devonian) from Hungry Hollow, Ontario, Canada. Canadian Journal of Earth Science 45, 353-366. DOI 10.1139/E08-005

Van Viersen, A. 2007. Preliminary report of trilobites from the Hanonet Formation (Eifelian-Givetian transition), southern border of Dinant Synclinorium, Belgium. Bulletin de l'Institut royal des Sciences naturelles de Belgique 77, 15-29.

VerriLl, A.E. 1865. Classification of polyps (Extract condensed from a synopsis of the polypi of the North Pacific Exploring Expedition, under captains Ringgold and Rogers, U.S.N.). Communications of the Essex Institute 4, 145-149.

Walliser, O.H. (ed.) 1996. Global Events and Event Stratigraphy in the Phanerozoic. 333 pp. Springer-Verlag, Berlin. DOI 10.1007/978-3-642-79634-0

Webster, C.L. 1889. Description of a new genus of corals from the Devonian rocks of Iowa. The American Naturalist 23 (272), 710-712. DOI 10.1086/274909

Wedekind, R. 1922. Zur Kenntnis der Stringophyllen des oberen Mitteldevon. Sitzungsberichte der Gesellschaft zur Beförderung der gesamten Naturwissenschaften zu Marburg 1921(1), 1-16.
Wedekind, R. 1923. Die Gliederung des Mitteldevons auf Grund von Korallen. Sitzungsberichte der Gesellschaft zu Beförderung der gesamten Naturwissenschaften zu Marburg 1922(4), 24-35.

Wedekind, R. 1924. Das Mitteldevon der Eifel. Eine biostratigraphische Studie. I. Teil. Die Tetrakorallen des unteren Mitteldevon. Schriften der Gesellschaft zur Beförderung der gesamten Naturwissenschaften zu Marburg 14(3), 1-93.

Wedekind, R. 1925. Das Mitteldevon der Eifel. Eine biostratigraphische Studie. II. Teil. Die Materialien zur Kenntnis des mittleren Mitteldevon. Schriften der Gesellschaft zur Beförderung der gesamten Naturwissenschaften zu Marburg 14(4), 1-85.

Weissermel, W. 1894. Die korallen der silurgeschiebe Ostpreussens und östlichen Westpreussens. Zeitschrift der Deutschen Geologischen Gesellschaft 46, 580-674.

Wright, A.J., Coen-Aubert, M., Bultynck, P. \& VAn Viersen, A.P. 2010. New data on occurrences of the Devonian rugose coral Calceola in Belgium. Memoirs of the Association of Australasian Palaeontologists 39, 121-129.

WrzoŁeK, T. 2002. Siphonophrentidae (Rugosa) in the Devonian of Poland. Coral Research Bulletin 7, 229-240.

ZIEGLER, P.A. 1982. Geological atlas of the Western and Central Europe. 130 pp. Shell International Petroleum Maatschappij BV.

Appendix. Location of the different sampled localities (see Fig. 2) - [outcrop ID of the Belgian Geological Survey].

1. Mont de Baileux quarry and outcrops (Baileux zoning) N of Baileux - 50 02' 26" N, 4 $4^{\circ} 23^{\prime} 35^{\prime \prime} \mathrm{E}$ and $50^{\circ} 02^{\prime} 16^{\prime \prime} \mathrm{N}, 4^{\circ} 23^{\prime} 04^{\prime \prime} \mathrm{E}$.

2. La Couvinoise (or Haine) quarry in Couvin $-50^{\circ} 03^{\prime} 37^{\prime \prime} \mathrm{N}, 4^{\circ} 29^{\prime} 25^{\prime \prime} \mathrm{E}$ [5780578].

3. Tienne Sainte-Anne (Nismes) - 50 $04^{\prime} 06^{\prime \prime} \mathrm{N}, 4^{\circ} 33^{\prime} 05^{\prime \prime} \mathrm{E}$ [5850449].

4. Fond des Vaux sections (Wellin) - from $50^{\circ} 05^{\prime} 27^{\prime \prime} \mathrm{N}, 5^{\circ} 06^{\prime} 56^{\prime \prime} \mathrm{E}$ to $50^{\circ} 05^{\prime} 36^{\prime \prime} \mathrm{N}, 5^{\circ} 07^{\prime} 03^{\prime \prime} \mathrm{E}$ [5960632-33].

5. Resteigne disused quarry $-50^{\circ} 05^{\prime} 24^{\prime \prime} \mathrm{N}, 5^{\circ} 10^{\prime} 35^{\prime \prime} \mathrm{E}$ [5960606].

6. Jemelle quarry $-50^{\circ} 16^{\prime} 44^{\prime \prime} \mathrm{N}, 5^{\circ} 26^{\prime} 73^{\prime \prime} \mathrm{E}$ [5931006].

7. Hampteau disused quarry $-50^{\circ} 15^{\prime} 35^{\prime \prime} \mathrm{N}, 5^{\circ} 27^{\prime} 53^{\prime \prime} \mathrm{E}$ [5550464]. 